Note: This is pre-published version of manuscript published as follows.

Full Citation: Shah, S.G.S. and Farrow, A. (2012) Trends in the Availability and Usage of Electrophysical Agents in Physiotherapy Practices from 1990 to 2010: A Review. Physical Therapy Reviews, 17(4): 207-226. http://dx.doi.org/10.1179/1743288x12y.0000000007

\title{
Trends in the Availability and Usage of Electrophysical Agents in Physiotherapy practices from 1990 to 2010: A
} review

\section{Syed Ghulam Sarwar Shah ${ }^{1,2^{*}}$ Alexandra Farrow ${ }^{1}$}

${ }^{1}$ School of Health Sciences and Social Care, Brunel University, Uxbridge, UB8 3PH, UK ${ }^{2}$ Multidisciplinary Assessment of Technology Centre for Heald care, Department of Information Systems and Computing, Brunel University bridge, UB8 3PH, UK ${ }^{*}$ Corresponding Author

Tel.: 0044-(0)-1895-265-463

E-mail: Sarwar.Shah@brunel.ac.uk

${ }^{2}$ Current address

\section{Abstract}

Background: The use electrophysical agents has a historically important role in physiotherapy practice. There are anecdotal reports that the availability and usage of electrotherapy modalities is declining, which may have implications for physiotherapy practice. she aim of the literature review was to provide scientific evidence on electhotherapy usage in the last twenty years by identifying trends in availability, use and nor-use of electrotherapeutic modalities in physiotherapy practice during 1990 s and 2000s.

Methods: Review of empirical studies published in the English language from 1990 to 2010 and identified through searching online bibliographic databases, which included Medline / OvidSP, PubMed Central, CINAHL/EBSCOhost, ScienceDirect, Scopus, ISI Web of Science and Google Scholar.

Findings: In the last twenty years, ultrasound availability and usage show increasing trends in several countries. The availability and use of pulsed shortwave diathermy 
(PSWD) and laser have shown steady trends. Transcutaneous electrical nerve stimulation (TENS), interferential and biofeedback availability and usage have shown increasing trends in the UK and decreasing trends in Australia and the Republic of Ireland. Trends of continuous shortwave diathermy (CSWD) availability and use are declining irrespective of the country of the study. The availability and usage of microwave diathermy (MWD) and $\mathrm{H}$-wave show steeply declining trends while there is a sharp rise in their non-availability over the last several years.

Conclusions: The availability and use of electrophysical agents have greatly changed in 6 the last twenty years. Declining trends in the availability and usage along with rising trend of non-availability of electrotherapy modalities may have implications fond: electrotherapy education, training and the practice in the coming years.

Keywords: electrotherapy, physical therapy, physiotherapy, survey therapeutic diathermy, therapeutic ultrasound, thermal modality.

\section{INTRODUCTION}

Electrotherapy is the main module of physiotherapy practice. ${ }^{1,2}$ It is provided using different electrophysical agents (EPAs) surên as therapeutic ultrasound, shortwave diathermy (used in pulsed (PSWD) and continuous (CSWD) modes), microwave diathermy (MWD), interferential ito biofeedback, laser, and H-wave?2-4

The use of electricaty energy for therapeutic purpose goes back as far as the $18^{\text {th }}$ century. ${ }^{5}$ Electrotherapy has been used for treating different medical conditions ${ }^{6}$. For example, use of diathermy for treating various gynaecological conditions ${ }^{7}$ such as the use of microwave eliathermy before conception and during early pregnancy. ${ }^{8}$ In addition, shortwa diathermy has been used as early as in 1940 for treating nasal sinus infectorns. ${ }^{9}$ In addition, a number of other electrotherapy modalities have been introduced and used since late 1980s and early 1990.10 However, some of electrotherapy modalities most commonly used in the past are becoming less popular ${ }^{2}$ while other electrotherapy modalities have become popular. For example, PSWD, used since its' development in the $1940 \mathrm{~s}^{11}$ became popular, ${ }^{12}$ but more recently has started declining. ${ }^{13}$ In addition, interferential, despite not being very new, also became popular among physiotherapists in the 1980s and thereafter. ${ }^{14,15}$ Moreover, some electrotherapy modalities most commonly used in the past have become less popular. ${ }^{2}$ For example, CSWD used widely since the 1930s started declining in the 1950 s $^{13}$ and by 2007 is rarely 
used. ${ }^{11,13,16}$ MWD used frequently before the $1970 \mathrm{~s}^{17}$ became rarely used in recent years in Australia ${ }^{16,18}$ while since 2007 it is not available and therefore not used in the UK. ${ }^{16}$ Conversely, very recently ultrasound, TENS, and interferential enjoyed the status of the most commonly available and used electrotherapy modalities.1, 16, 18 In addition, either using or not using a particular EPA has become a challenge in physiotherapy practice for a number of reasons, such as physiotherapists' use of evidence based practice, emphasis on physical exercise and manual therapies as well as a lack of evidence in clinical effectiveness of electrotherapy modalities. $2,19,20$ Hence, there may be implications for teaching and training of electrotherapy in the physiotherapy discipline. 19, 21, 22 For example, there has been exclusion of MWD from a very recent text book on electrotherapy. ${ }^{20}$ It is therefore important to assess scientific evidence as to the degree to which electrotherapy modalities are available and used, available but note-used and notavailable in physiotherapy practices. There is however no systematid study to inform the trends in the usage of electrotherapeutic modalities. Thereforere is a need to fill this gap in the literature and update the body of knowledge on thê usage of electrotherapy modalities.

\section{Aims and objectives}

The aim of this systematic literature reviendois to provide a scientific evidence on trends in the availability and usage of nine different types of electrotherapeutic modalities i.e. ultrasound, PSWD, CSWD, MWD, iterferential, TENS, biofeedback, laser and H-wave in physiotherapy practices in the ast twenty years from 1990 to 2010.

\section{METHODS}

\section{Definition of RAysiotherapy practice}

In this reatew, the term physiotherapy practice was defined as 'any physiotherapy depantment or clinic in the public or private healthcare sector'.

\section{Electrophysical agents studied}

Electrophysical agents included in this review were therapeutic ultrasound, radiofrequency electromagnetic radiation (pulsed shortwave diathermy (PSWD), continuous shortwave diathermy (CSWD), microwave diathermy (MWD), interferential, transcutaneous electrical nerve stimulation (TENS), biofeedback, laser and H-wave. 


\section{Inclusion criteria}

Inclusion criteria were empirical primary research studies in the English language published between January 1990 and June 2010. Study designs included were cross sectional surveys and audits of electrotherapy equipment, availability, use and non-use in physiotherapy departments and clinics. The outcomes investigated included the availability and usage of any or all of the nine electrotherapy modalities mentioned above.

\section{Exclusion criteria}

Discursive, hypothetical and review articles and studies in languages other thandish.

\section{Databases searched}

Literature searches were conducted through several online bibliogitaphic databases i.e. Medline / OvidSP, PubMed Central, CINAHL/EBSCOhost, Scieucededirect, Scopus, ISI Web of Science and Google Scholar.

\section{Keywords used}

The keywords used for literature searches ere: electrotherapy, equipment, survey, electrophysical agents, physiotherapy, ed ectrotherapeutic, devices, use, usage, availability, therapeutic, diathermy, microwave shortwave. These keywords were searched using two Boolean search operators id 'AND' and 'OR' through the above mentioned bibliographic databases. Theprocess of the literature search is explained below.

\section{Search strategy, grêicle shortlisting and data abstraction}

A team of twgeresearchers (the authors) were involved in the literature review process. Using the shorthisted and reviewed the relevant articles and abstracted the data. AF supervised the process of the literature review and checked the abstracted data, which involved referring back to the original article(s) if required. Abstracted data was accepted with the consensus of both researchers (the authors).

The process of identification of relevant articles included reading the title, followed by review of the abstract and creation of a shortlist of relevant articles for full review. The process of selecting the research, shown in Figure 1 led to identification of 23 studies. Full text was obtained for these studies ( $n=23)$, which were reviewed and the data was abstracted for the publication year, location of the study, aims and objectives, 
study design, data collection tool, sample size, response rate and the key findings with respect to the availability, use, non-use and non-availability of the nine electrotherapy modalities as shown in Table 1. This table also provides the reviewers' / authors' (our) comments / remarks on the studies included in this review. In a study by Pope et al.,23 the authors only reported the total number of physiotherapists who had access to different electrotherapy modalities but they did not report the absolute number revealing the overall availability of devices for each modality surveyed in their study.

The present authors (reviewers) therefore determined the availability of electrotherapy modalities by the number of physiotherapists who had access to equipment of each modality divided with the total respondents in the study by Rope et al. ${ }^{23}$ In addition, for studies that only reported equipment availability, we determined non-availability of equipment using the following formula.

Non-availability of equipment $(\%)=$ (total respondentsutho reported equipment availability / total respondents in the study) $\times 100$ 
66 articles identified through title review of search results

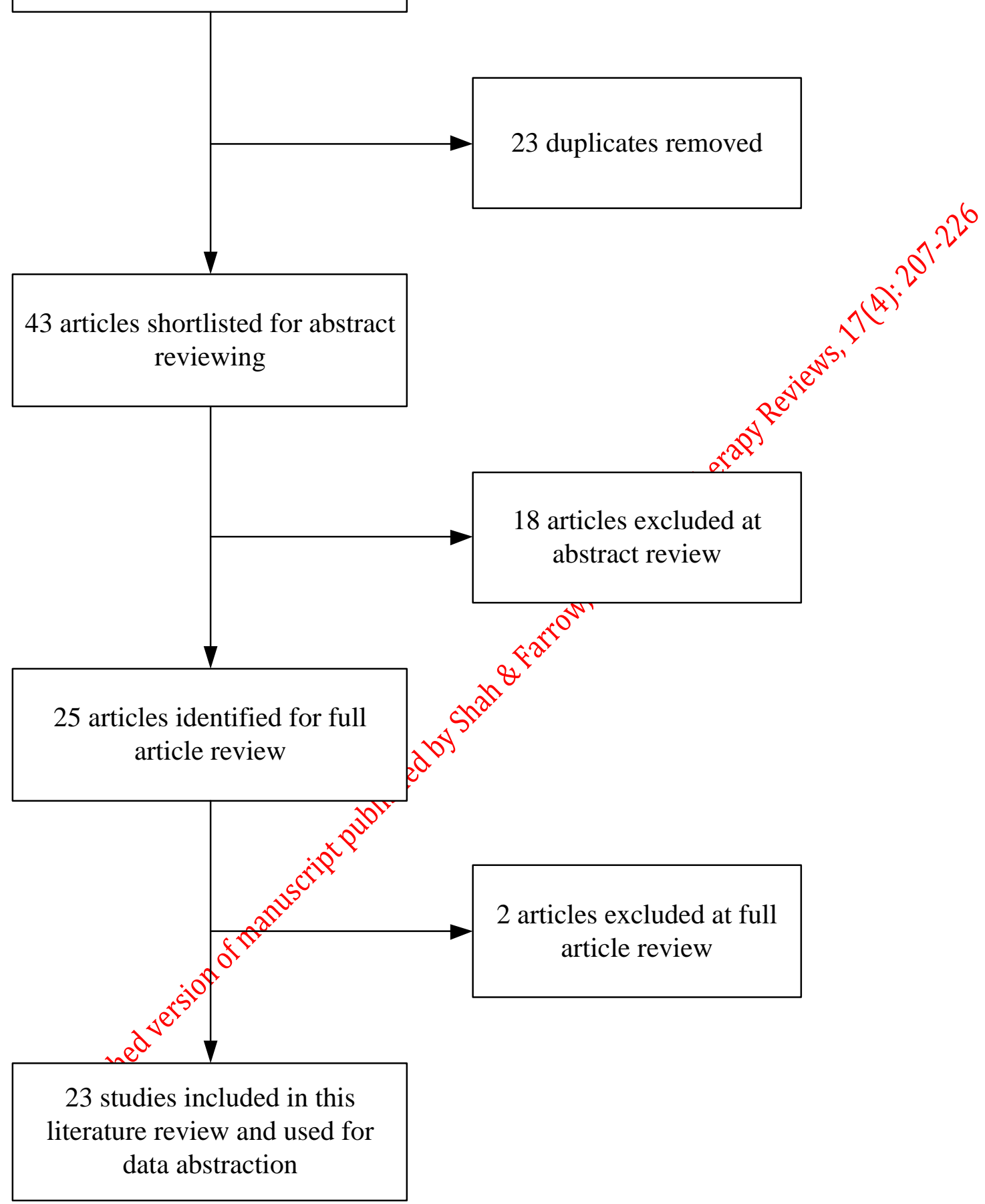

Figure 1 Flow chart of studies included and excluded in this literature review 
Table 1 Data extracted from reviewed studies on the availability and usage of electrophysical agents in physiotherap $2 y^{6}$ practices

\begin{tabular}{|c|c|c|c|c|c|c|}
\hline Authors (year) & Location & Aims/objectives & $\begin{array}{l}\text { Participants; } \\
\text { Sample size= N }\end{array}$ & $\begin{array}{l}\text { Design; } \\
\text { (Response } \\
\text { rate) }\end{array}$ & $e^{s^{2}}$ & Reviewers' comments \\
\hline $\begin{array}{l}\text { Lindsay et al. } \\
1990^{24}\end{array}$ & $\begin{array}{l}\text { Brisbane, } \\
\text { Australia }\end{array}$ & $\begin{array}{l}\text { Survey of } \\
\text { ownership, } \\
\text { frequency of use } \\
\text { and factors } \\
\text { affecting the } \\
\text { pattern of use of } \\
\text { electrotherapeutic } \\
\text { modalities }\end{array}$ & $\begin{array}{l}\text { Private } \\
\text { physiotherapy } \\
\text { practices; } \\
\mathrm{N}=105\end{array}$ & $\begin{array}{l}\text { Questionnaire } \\
\text { survey; } \\
(70 \%)\end{array}$ & 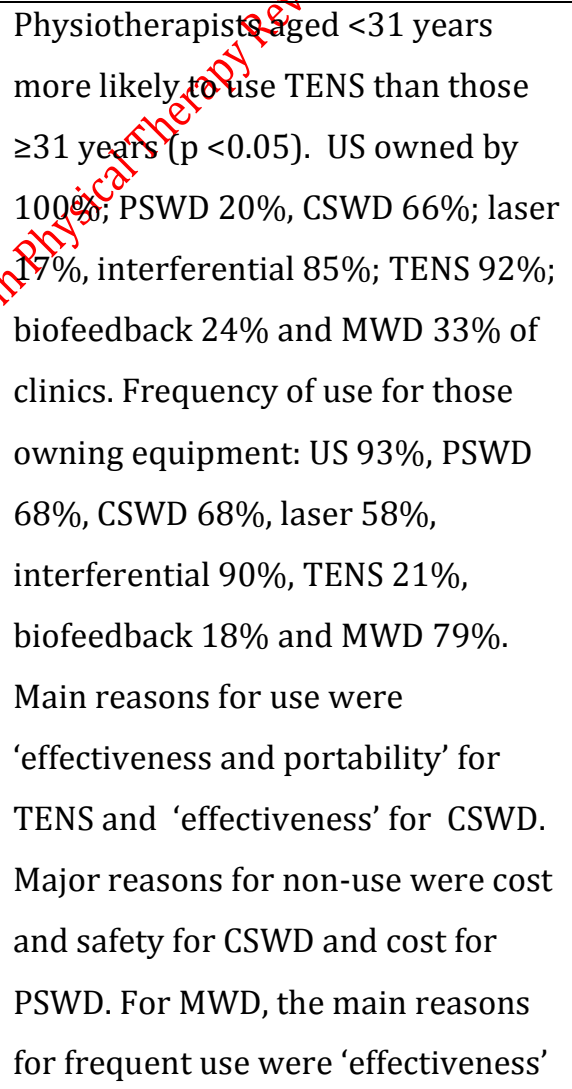 & $\begin{array}{l}\text { Issues of safety, whether for the } \\
\text { physiotherapist, the patient or } \\
\text { both were not clear. No report on } \\
\text { the number of devices available } \\
\text { in each practice. This small study } \\
\text { included only private clinics in } \\
\text { Brisbane and findings cannot } \\
\text { therefore be generalized, but } \\
\text { suggested a regional trend of } \\
\text { electrotherapy. }\end{array}$ \\
\hline
\end{tabular}




\begin{tabular}{|c|c|c|c|c|c|c|}
\hline & & & & & $\begin{array}{l}\text { and 'ease of application' and safety } \\
\text { was the main concern for non-use. } \\
\text { The reasons for non-ownership were } \\
\text { cost, unfamiliarity and questionable } \\
\text { effects for laser and a lack of need for } \\
\text { biofeedback. }\end{array}$ & \\
\hline $\begin{array}{l}\text { Baxter et al. } \\
199925\end{array}$ & $\begin{array}{l}\text { Northern } \\
\text { Ireland } \\
\text { (UK) }\end{array}$ & $\begin{array}{l}\text { To evaluate use of } \\
\text { therapeutic laser }\end{array}$ & $\begin{array}{l}\text { Physiotherapists; } \\
\mathrm{N}=148\end{array}$ & $\begin{array}{l}\text { Postal } \\
\text { Questionnaire } \\
\text { Survey in } 2 \\
\text { stages; (63\%, }\end{array}$ & $\begin{array}{l}\text { Therap fictc laser was used mainly } \\
\text { for burns but also for rheumatoid } \\
\text { especially about the parameters of } \\
\text { optimal treatment with laser was } \\
\text { reported. }\end{array}$ & $\begin{array}{l}\text { No information presented on the } \\
\text { number of devices per } \\
\text { department. Research design and } \\
\text { selection of the sample was not } \\
\text { clear. This was a regional study } \\
\text { and therefore not generalizable } \\
\text { but suggested a regional trend of } \\
\text { laser usage in clinical practice. }\end{array}$ \\
\hline $\begin{array}{l}\text { Taylor and } \\
\text { Humphry } \\
1991^{26}\end{array}$ & USA & $\begin{array}{l}\text { Use of } \\
\text { electrophysical } \\
\text { agent modalities }\end{array}$ & $\begin{array}{l}\text { Physiotherapises } \\
\text { (specialistitis } \\
\text { physicilected) }\end{array}$ & $\begin{array}{l}\text { Postal } \\
\text { Questionnaire } \\
\text { Survey; (63\%, } \\
n=629 \text { ) }\end{array}$ & $\begin{array}{l}\text { Figures on availability of devices not } \\
\text { reported. Hot and cold packs were } \\
\text { most commonly used. Use of US was } \\
\text { 86\%, TENS 88\% and neuromuscular } \\
\text { electrical stimulation (NMES) 89\%. } \\
\text { Use of several times / week equal for } \\
\text { NMES and US but lower for TENS. } \\
\text { Non-use was highest for US (14\%) }\end{array}$ & $\begin{array}{l}\text { Limited scope of the study on use } \\
\text { of EPAs because participants } \\
\text { were from one specialist group of } \\
\text { physiotherapists in physical } \\
\text { disabilities practice. Not known } \\
\text { whether this survey covered both } \\
\text { public and private practices. No } \\
\text { precise data given on overall }\end{array}$ \\
\hline
\end{tabular}




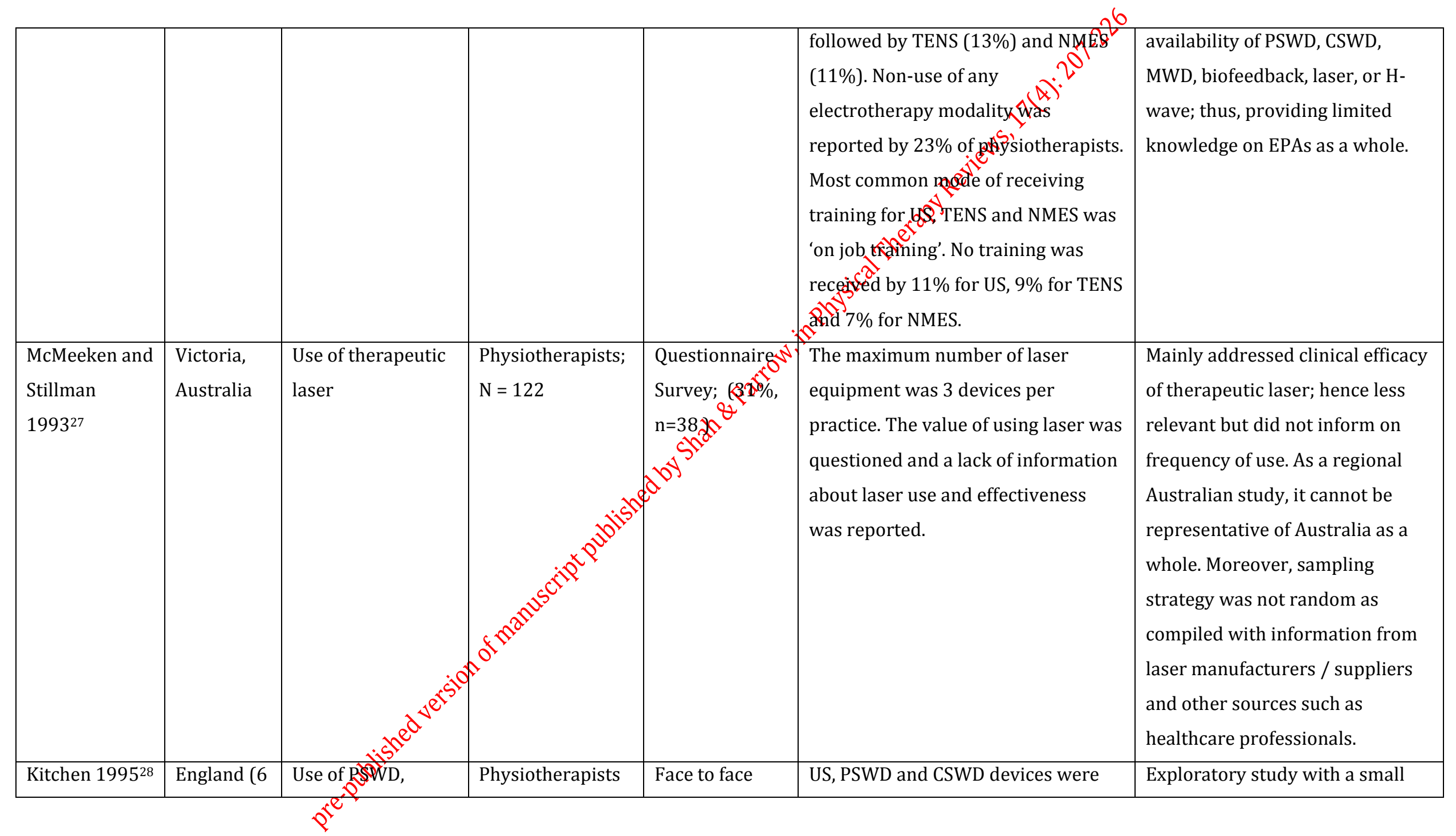




\begin{tabular}{|c|c|c|c|c|c|c|}
\hline & $\begin{array}{l}\text { health } \\
\text { regions) }\end{array}$ & $\begin{array}{l}\text { CSWD, ultrasound } \\
\text { and laser in clinical } \\
\text { practice }\end{array}$ & $\begin{array}{l}\text { (NHS and } \\
\text { private); } \mathrm{N}=10\end{array}$ & $\begin{array}{l}\text { interviews; } \\
(100 \%, n=10) \\
\text { की }\end{array}$ & $\begin{array}{l}\text { available to all participants (n=109) } \\
\text { while laser equipment was available } \\
\text { to } 40 \% \text { (n=4) of participants. } \\
\text { Personal experience âd availability } \\
\text { were the two main reasons for } \\
\text { selection of the modalities. Doubts } \\
\text { about the efficacy of electrotherapy } \\
\text { ageajts were also reported. The } \\
\text { Occurrence of a number of adverse } \\
\text { reactions due to these modalities } \\
\text { was reported. }\end{array}$ & $\begin{array}{l}\text { sample (n=10) over six health } \\
\text { regions; location of the health } \\
\text { regions was not described. Mainly } \\
\text { referred to use of CSWD, PSWD, } \\
\text { US and laser for management of } \\
\text { soft-tissue problems and the } \\
\text { factors affecting the selection of } \\
\text { the modality. Hence, this study } \\
\text { has less value for assessing the } \\
\text { availability and use / non-use of } \\
\text { EPAs. The occurrence of adverse } \\
\text { reactions was not clear whether } \\
\text { patients or physiotherapists } \\
\text { experienced them. }\end{array}$ \\
\hline $\begin{array}{l}\text { Lindsay et al. } \\
1995^{29}\end{array}$ & $\begin{array}{l}\text { Alberta, } \\
\text { Canada }\end{array}$ & $\begin{array}{l}\text { To survey all } \\
\text { private } \\
\text { practitioners } \\
\text { registered within } \\
\text { the Province of } \\
\text { Alberta regarding } \\
\text { modality usage }\end{array}$ & $\begin{array}{l}\text { Physiotherapists, } \\
\mathrm{N}=\text { all prite } \\
\text { practikfoners } \\
\text { registered within } \\
\text { Alberta }\end{array}$ & $\begin{array}{l}\text { Questionnaire } \\
\text { Survey; (41\%, } \\
\mathrm{n}=208)\end{array}$ & $\begin{array}{l}\text { Electrotherapy was a common } \\
\text { treatment mode. US, interferential } \\
\text { and TENS were most frequently } \\
\text { used. Frequent use of TENS was } \\
\text { greater amongst older } \\
\text { physiotherapists and clinic owners } \\
\text { (p<0.05). [Similar to } 1990 \text { results } \\
\text { by same researchers carried out in }\end{array}$ & $\begin{array}{l}\text { Reported availability of PSWD } \\
\text { and CSWD equipment as 'high' } \\
\text { but did not report exact number } \\
\text { of devices per department. There } \\
\text { was no report on the non-use of } \\
\text { modalities. Moreover, this study } \\
\text { covered only private } \\
\text { physiotherapists in the region of }\end{array}$ \\
\hline
\end{tabular}




\begin{tabular}{|c|c|c|c|c|c|c|}
\hline & & & & & $\begin{array}{l}\text { Australia }{ }^{24} \text { ] Male physiotherapistst } \\
\text { use of biofeedback was greaterthan } \\
\text { female physiotherapists' use of this } \\
\text { modality }(p<0.05) \cdot e^{\text {s. }}\end{array}$ & $\begin{array}{l}\text { Alberta; hence, the findings could } \\
\text { not be representative of } \\
\text { physiotherapists in both public } \\
\text { and private sectors across } \\
\text { Canada. }\end{array}$ \\
\hline $\begin{array}{l}\text { Pope et al. } \\
1995^{23}\end{array}$ & England & $\begin{array}{l}\text { To study } \\
\text { ownership and use } \\
\text { of electrotherapy } \\
\text { equipment }\end{array}$ & $\begin{array}{l}\text { Senior } \\
\text { physiotherapists } \\
\text { in } 139 \text { hospitals } \\
\text { in } 14 \text { regional } \\
\text { health Authorities } \\
\text { (RHAs), random } \\
\text { sampling }\end{array}$ & $\begin{array}{l}\text { Questionnaire } \\
\text { Survey; (84\%, } \\
\mathrm{n}=116 \\
\text { hospitals) }\end{array}$ & $\begin{array}{l}\text { More than ondreply from each } \\
\text { hospitaktotal replies = 213. The } \\
\text { laser 196, interferential 207, TENS } \\
\text { 209, biofeedback 176, MWD } 178 \text { and } \\
\text { H-wave } 173 \text { respondents. Use with } \\
\text { ownership was US 100\%, PSWD } \\
\text { 97\%, CSWD 65\%, laser 93\%, } \\
\text { interferential 99\%, TENS 99\%, } \\
\text { biofeedback 94\% and MWD 64\% and } \\
\text { H-wave 97\%. Non-use despite } \\
\text { ownership was PSWD by 3\%, CSWD } \\
\text { 35\%, laser 7\%, interferential 0.5\%, } \\
\text { TENS 1\%, biofeedback 6\%, MWD } \\
\text { 36\% and H-wave 3\%. Reasons for } \\
\text { non-use despite ownership for US }\end{array}$ & $\begin{array}{l}\text { No exact sample size of } \\
\text { physiotherapists reported. } \\
\text { Report of final response rate was } \\
\text { not clear as to whether response } \\
\text { was a hospital or a } \\
\text { physiotherapist. Figures on } \\
\text { ownership and use / non-use } \\
\text { were not clearly reported. No } \\
\text { explanation of unfamiliarity with } \\
\text { some modalities given. Some of } \\
\text { the hospitals provided more than } \\
\text { one response. }\end{array}$ \\
\hline
\end{tabular}




\begin{tabular}{|c|c|c|c|c|c|c|}
\hline & & & & & $\begin{array}{l}\text { were not reported. Most common. } \\
\text { reasons for not purchasing CSWD, } \\
\text { laser, biofeedback, MWRand H-wave } \\
\text { equipment were unfawililiarity with } \\
\text { the modalities, ge of clinical } \\
\text { evidence and }\end{array}$ & \\
\hline $\begin{array}{l}\text { Kitchen and } \\
\text { Partridge } \\
1996^{30}\end{array}$ & England & $\begin{array}{l}\text { Survey of } \\
\text { availability and } \\
\text { frequency of use } \\
\text { US, SWD and laser } \\
\text { for treating of soft } \\
\text { tissue lesions } \\
\text { (Part-1) }\end{array}$ & $\begin{array}{l}\text { Physiotherapists, } \\
\mathrm{N}=111 \text { (in } 14 \\
\text { NHS outpatient } \\
\text { departments, one } \\
\text { each in } 14 \text { health } \\
\text { services regions), } \\
\text { stratified random } \\
\text { sampling }\end{array}$ & $\begin{array}{l}\text { Postal } \\
\text { Questionnaire } \\
\text { Survey; (89\%, } \\
\text { n=99). } \\
\text { Responses } \\
\text { analyzed = }\end{array}$ & $\begin{array}{l}\text { Availabity of equipment of US } \\
\text { (pulsed and continuous) was 100\%, } \\
\text { once per week: pulsed US 76\%, } \\
\text { continuous US 56\%, PSWD 76\%, } \\
\text { CSWD 16\% and laser 32\%. Overall, } \\
\text { laser was used by } 97 \% \text { of (i.e. } 32 \text { out } \\
\text { of 33) physiotherapists with access } \\
\text { to it. Physiotherapists preferred the } \\
\text { use of non-thermal modalities } \\
\text { (PSWD) to thermal modalities } \\
\text { (CSWD) in treating a variety of soft } \\
\text { tissue lesions at the NHS outpatients } \\
\text { departments. }\end{array}$ & $\begin{array}{l}\text { A very high response rate was } \\
\text { achieved but the participants } \\
\text { were only those physiotherapists } \\
\text { who used electrotherapy and not } \\
\text { every physiotherapist working in } \\
\text { a participating department; } \\
\text { hence, the findings might be less } \\
\text { representative. Moreover, the } \\
\text { focus of this study was on the } \\
\text { types of soft tissue lesions and } \\
\text { not on the types of electrotherapy } \\
\text { modalities. }\end{array}$ \\
\hline Seymour and & Trent & Survey or & Physiotherapists & Postal & Of respondents, 92\% were female, & No report on how many \\
\hline
\end{tabular}




\begin{tabular}{|c|c|c|c|c|c|c|}
\hline Kerr $1996^{31}$ & $\begin{array}{l}\text { region, } \\
\text { England }\end{array}$ & $\begin{array}{l}\text { community based } \\
\text { physiotherapists }\end{array}$ & $\begin{array}{l}\text { (community } \\
\text { based in Trent } \\
\text { RHA); N = } 150\end{array}$ & $\begin{array}{l}\text { Questionnaire } \\
\text { Survey; (65\%, } \\
\mathrm{n}=97) \\
\text { che }\end{array}$ & 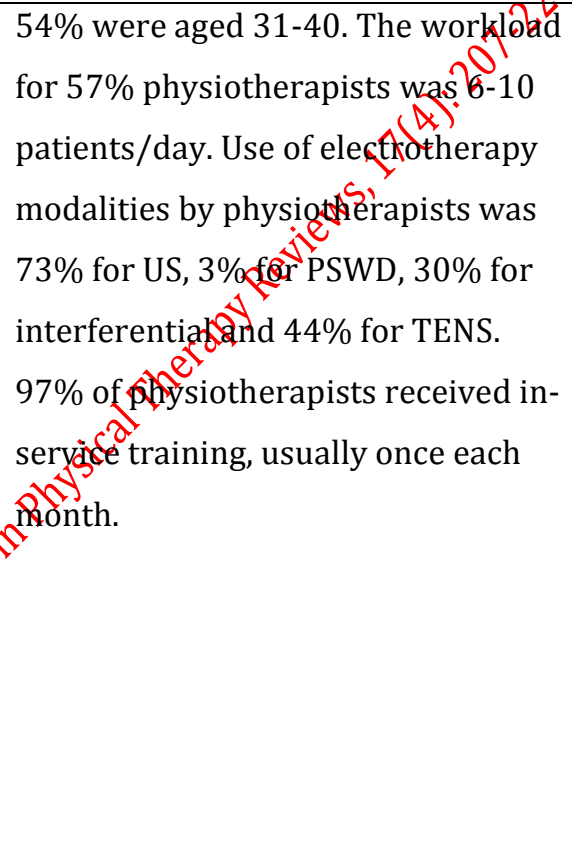 & $\begin{array}{l}\text { participants had access to } \\
\text { electrotherapy equipment and } \\
\text { how many did not use the } \\
\text { equipment despite availability. } \\
\text { This was another example of a } \\
\text { local study representing the area } \\
\text { covered by a health authority in } \\
\text { the north of England. Only public } \\
\text { sector community } \\
\text { physiotherapists were involved } \\
\text { providing limited information of } \\
\text { physiotherapists' practices within } \\
\text { the wider geographical } \\
\text { boundaries of the Trent RHA. }\end{array}$ \\
\hline $\begin{array}{l}\text { Kitchen and } \\
\text { Partridge } \\
199732\end{array}$ & England & $\begin{array}{l}\text { Study of use of US, } \\
\text { SWD and laser for } \\
\text { management of } \\
\text { soft tissue lesions } \\
\text { (Part-2) }\end{array}$ & 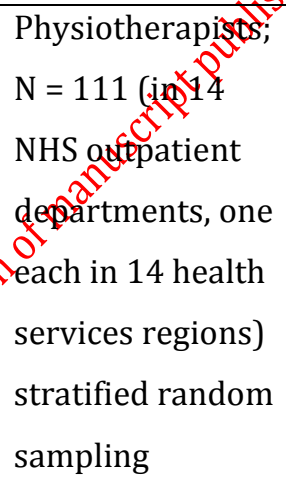 & $\begin{array}{l}\text { Postal } \\
\text { Questionnaire } \\
\text { Survey; (89\%, } \\
\text { n=99). } \\
\text { Responses } \\
\text { analyzed= } 98\end{array}$ & $\begin{array}{l}\text { The pattern of availability and use of } \\
\text { US, PSWD, CSWD and laser was the } \\
\text { same as reported in the above } \\
\text { mentioned study by Kitchen and } \\
\text { Partridge (1996) }{ }^{31} \text {, which was part-1 } \\
\text { of this study. In addition, this article } \\
\text { reported a number of factors } \\
\text { affecting selection of electrotherapy }\end{array}$ & $\begin{array}{l}\text { This was Part II of Kitchen and } \\
\text { Partridge (1996) study; hence, } \\
\text { our comments are the same as } \\
\text { those reported above for the said } \\
\text { study. }\end{array}$ \\
\hline
\end{tabular}




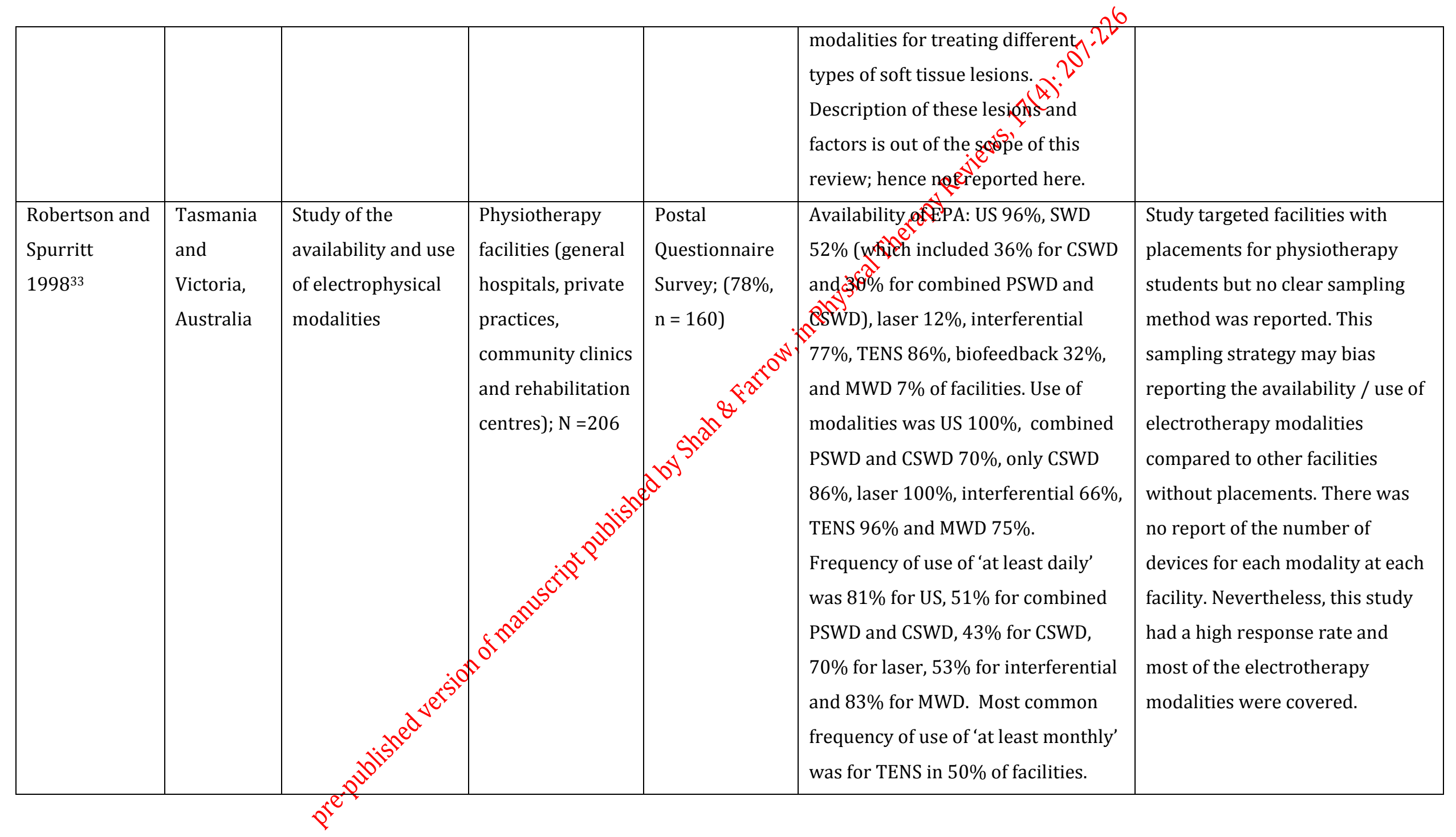




\begin{tabular}{|c|c|c|c|c|c|c|}
\hline & & & & & 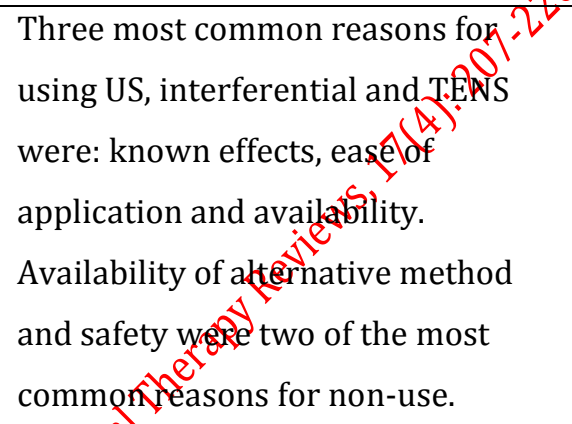 & \\
\hline $\begin{array}{l}\text { Partridge and } \\
\text { Kitchen } 1999^{34}\end{array}$ & $\begin{array}{l}\text { England } \\
\text { and Wales } \\
\text { (UK) }\end{array}$ & $\begin{array}{l}\text { Phase-I: Adverse } \\
\text { health of } \\
\text { electrotherapy in } \\
\text { patients) } \\
\text { Phase-II: Adverse } \\
\text { health in patients } \\
\text { with neurological } \\
\text { conditions }\end{array}$ & $\begin{array}{l}\text { Physiotherapy } \\
\text { departments in } \\
\text { NHS hospitals; N } \\
\text { = Phase-I = 200; } \\
\text { Phase-II= } 145\end{array}$ & 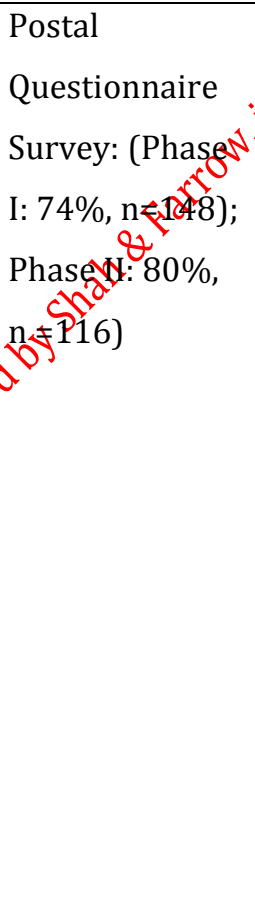 & $\begin{array}{l}\text { Phasi-1 did not report availability or } \\
\text { use of modalities reported for } \\
\text { patients and not relevant here. } \\
\text { Phase-II found } 52 \% \text { of } \\
\text { physiotherapists working in } \\
\text { neurology were in senior } 1 \text { grade. } \\
70 \% \text { did not use electrotherapy in } \\
\text { neurological conditions. Use of } \\
\text { electrotherapy during previous year } \\
\text { was reported by } 55 \% \text { for US, } 8 \% \text { for } \\
\text { SWD, } 7 \% \text { for laser. } 14 \% \text { for } \\
\text { interferential and } 58 \% \text { for TENS. } \\
\text { Remaining participants did not use } \\
\text { these modalities. }\end{array}$ & $\begin{array}{l}\text { Focus on health effects in } \\
\text { patients; therefore, less relevant } \\
\text { to this review. However, it } \\
\text { provided some data on the use of } \\
\text { EPAs. Use of SWD was reported } \\
\text { but no details of PSWD and CSWD } \\
\text { given. Study provided little } \\
\text { information on electrotherapy } \\
\text { modalities overall. }\end{array}$ \\
\hline
\end{tabular}




\begin{tabular}{|c|c|c|c|c|c|c|}
\hline $\begin{array}{l}\text { Cooney et al. } \\
2000^{35}\end{array}$ & $\begin{array}{l}\text { Republic of } \\
\text { Ireland }\end{array}$ & $\begin{array}{l}\text { Study of } \\
\text { availability and use } \\
\text { of electrotherapy } \\
\text { modalities in } \\
\text { public and private } \\
\text { physiotherapy } \\
\text { practices }\end{array}$ & $\begin{array}{l}\text { Physiotherapists; } \\
\mathrm{N}=120 \text { (public = } \\
40 \text { and private } \\
=80 \text { ) }\end{array}$ & $\begin{array}{l}\text { Postal } \\
\text { Questionnaire } \\
\text { Survey; (Total } \\
=72 \%, \mathrm{n}=86 \text {; } \\
\text { public sector = } \\
88 \%, \mathrm{n}=35 \text {; } \\
\text { private } \\
\text { practitioners = } \\
64 \%, \mathrm{n}=51 \text { ) } \\
\text { को }\end{array}$ & 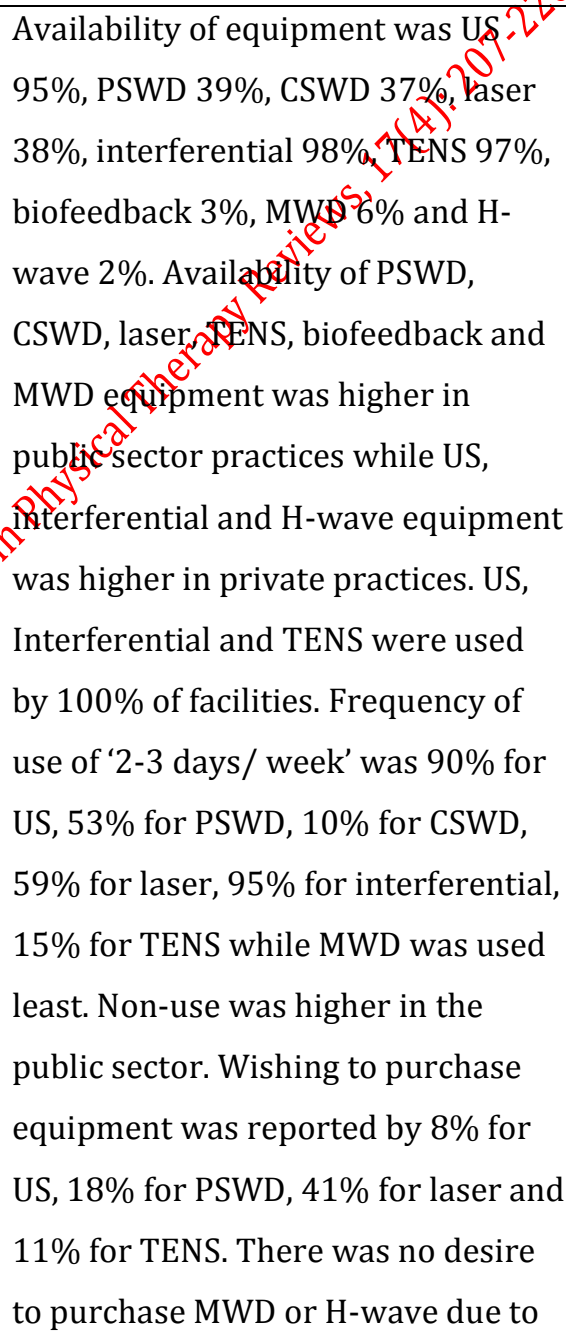 & $\begin{array}{l}\text { The sample size was small, } \\
\text { particularly for public sector } \\
\text { physiotherapists; thus, limiting } \\
\text { the generalizability of findings. } \\
\text { The reasons for selection or non- } \\
\text { use of the surveyed modalities } \\
\text { were not reported. None of the } \\
\text { modalities was reported to has } \\
\text { ceased to be used. However, the } \\
\text { study provided better } \\
\text { information on purchase of } \\
\text { equipment although it was } \\
\text { difficult to know the exact status } \\
\text { of device ownership. }\end{array}$ \\
\hline
\end{tabular}




\begin{tabular}{|c|c|c|c|c|c|c|}
\hline & & & & & $\begin{array}{l}\text { these being superseded by othef } \\
\text { modalities. Cost was the main } \\
\text { consideration for not buying PSWD, } \\
\text { CSWD and laser in private practices. }\end{array}$ & \\
\hline $\begin{array}{l}\text { Shields et al. } \\
2001^{36}\end{array}$ & $\begin{array}{l}\text { Republic of } \\
\text { Ireland }\end{array}$ & $\begin{array}{l}\text { Survey of the } \\
\text { availability, use, } \\
\text { age, non-use and } \\
\text { intention to } \\
\text { purchase PSWD } \\
\text { and CSWD }\end{array}$ & $\begin{array}{l}\text { Physiotherapy } \\
\text { facilities; } \mathrm{N}=240 \\
\text { (82 hospital } \\
\text { departments and } \\
158 \text { private } \\
\text { practices) }\end{array}$ & $\begin{array}{l}\text { Postal } \\
\text { Questionnaire } \\
\text { Survey; (Total } \\
=96 \%, \mathrm{n}=231 \text {; } \\
\text { hospital } \\
\text { departments } \\
95 \%, \mathrm{n}=7 \% \text {; } \\
\text { privatg } \\
\text { practices = } \\
\text { 97\%, n=153) }\end{array}$ & 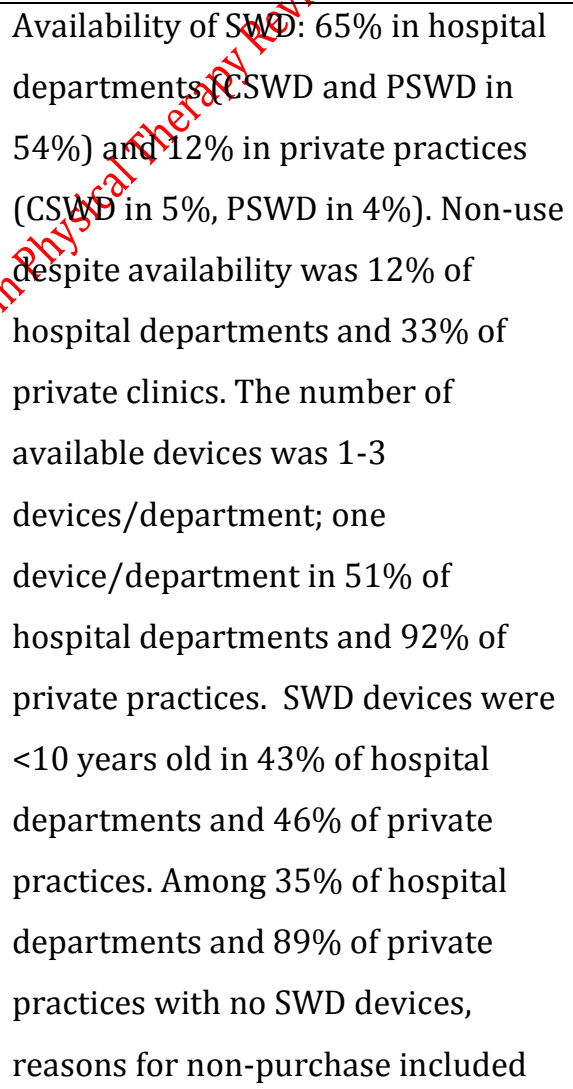 & $\begin{array}{l}\text { A high response rate, which } \\
\text { provides results that are the most } \\
\text { representative and more } \\
\text { generalizable. However, only } \\
\text { SWD was covered. No details on } \\
\text { safety issues (neither for patients } \\
\text { nor for physiotherapists) were } \\
\text { reported; however, the issue of } \\
\text { evidence on clinical effectiveness } \\
\text { of SWD (both PSWD and CSWD) } \\
\text { was raised. }\end{array}$ \\
\hline
\end{tabular}




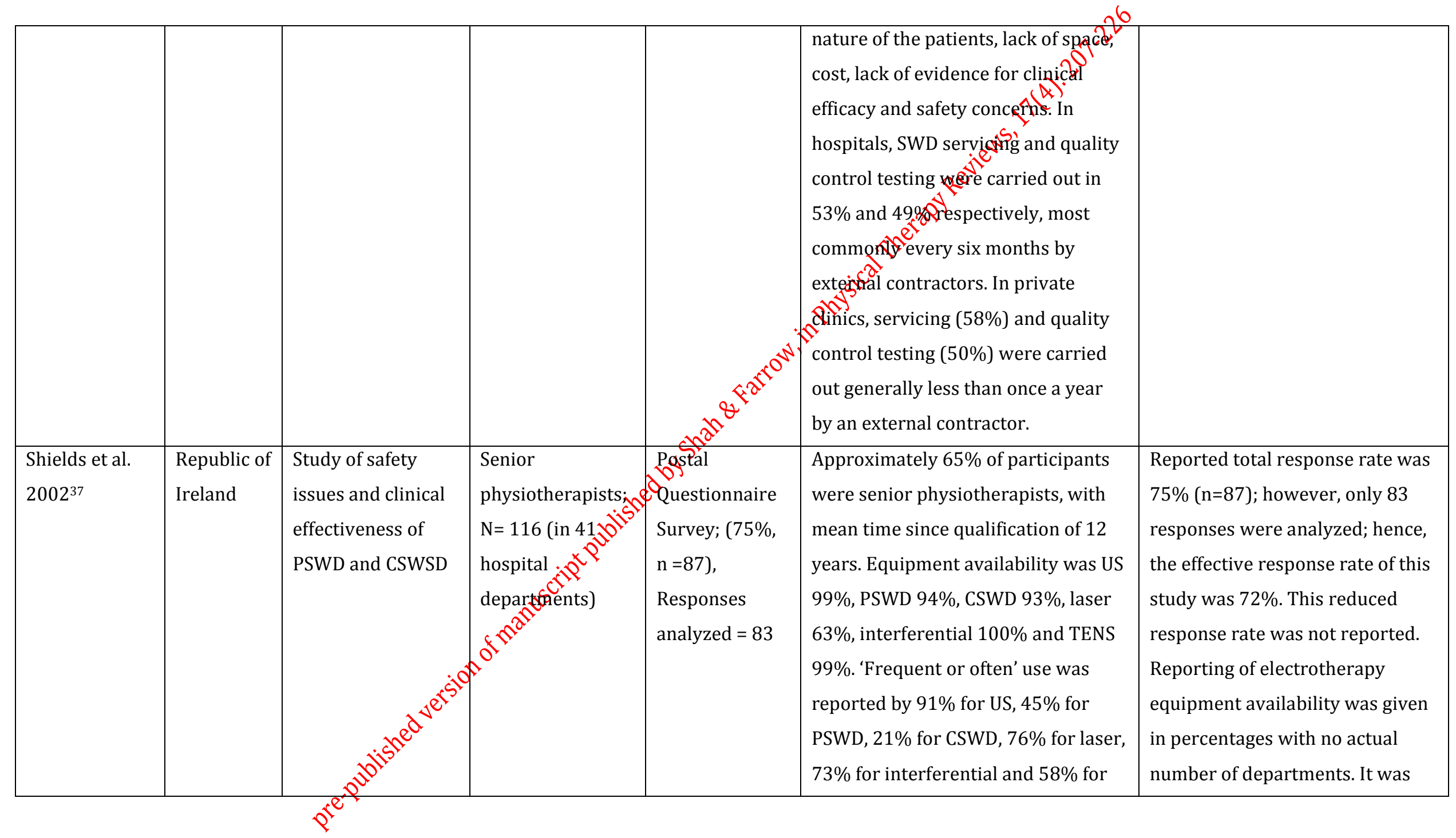




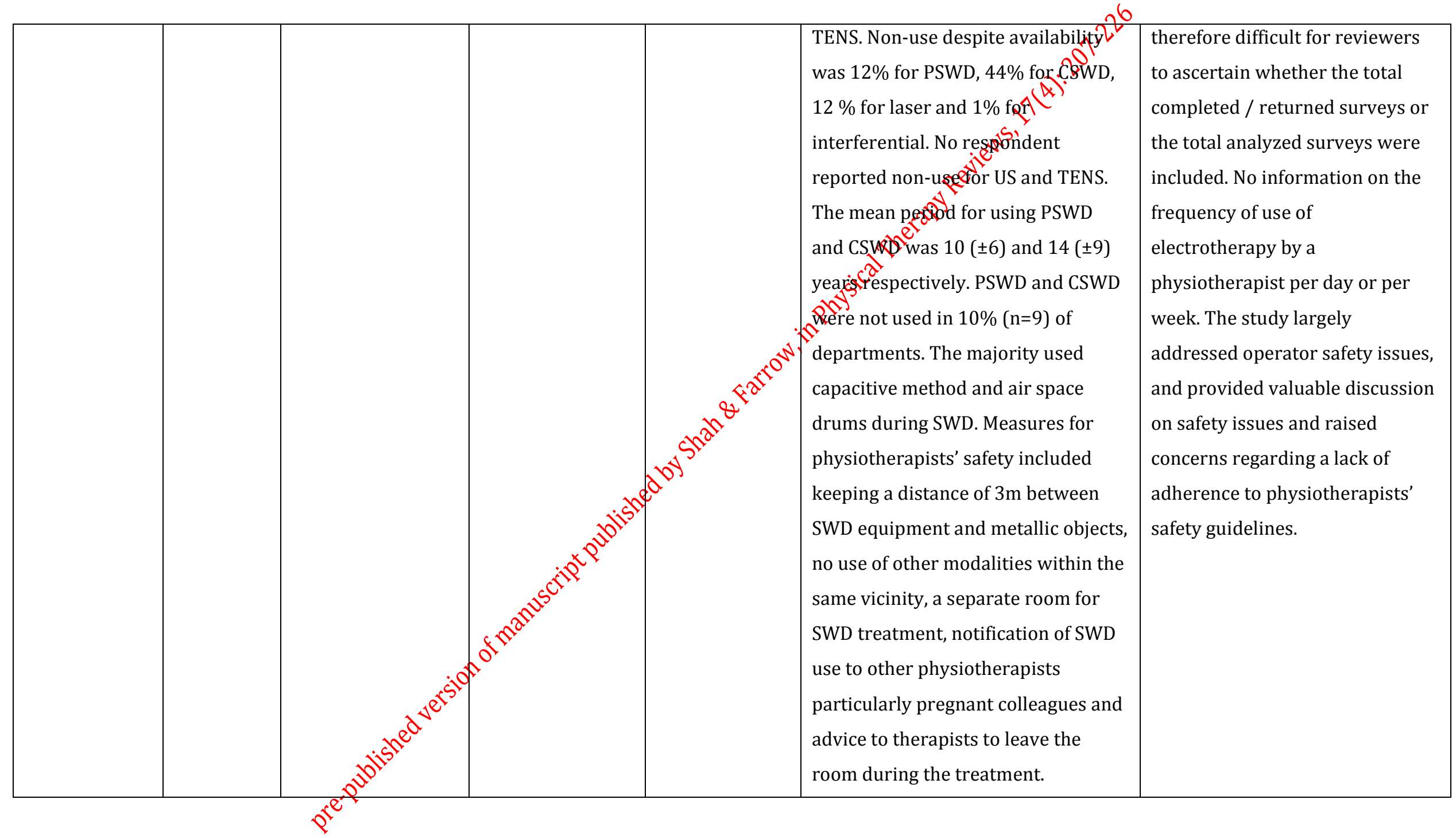




\begin{tabular}{|c|c|c|c|c|c|c|}
\hline & & & & & $\begin{array}{l}\text { However, taking no measures for. } \\
\text { physiotherapists' safety was. } \\
\text { reported by } 30 \% \text { of respondents. }\end{array}$ & \\
\hline $\begin{array}{l}\text { Warden and } \\
\text { McMeeken } \\
2002^{38}\end{array}$ & $\begin{array}{l}\text { Victoria, } \\
\text { Australia }\end{array}$ & $\begin{array}{l}\text { To assess the } \\
\text { availability, } \\
\text { frequency of use } \\
\text { and dose of } \\
\text { ultrasound in } \\
\text { treating sports } \\
\text { injuries }\end{array}$ & $\begin{array}{l}\text { Physiotherapists } \\
\text { (in sports } \\
\text { injuries); } \mathrm{N}=355\end{array}$ & $\begin{array}{l}\text { Postal } \\
\text { Questionnaire } \\
\text { Survey; (48\%, } \\
\mathrm{n}=171)\end{array}$ & $\begin{array}{l}\text { There were } 60 \% \text { males respondents } \\
\text { (n=102). Medianexperience (10 } \\
\text { years) and woxkload of } 15 \text { patients / } \\
\text { day. US aevices were available to all } \\
\text { resposidents. The most common } \\
\text { (84\%, n=143). Treatment with US = } \\
25 \% \text { of total patients; } 4 \text { patients / } \\
\text { day (median figures). The main } \\
\text { factors in deciding dose of US were } \\
\text { training during graduate degree } \\
\text { (83\%) and experience ( } 76 \% \text { ). Of } \\
\text { respondents, } 72 \% \text { reported a lack of } \\
\text { research evidence for US therapy. }\end{array}$ & $\begin{array}{l}\text { The response rate was } \\
\text { comparatively low and only } \\
\text { sports physiotherapists were } \\
\text { selected suggested a source of } \\
\text { bias in favour of champions for } \\
\text { providing US therapy for sports } \\
\text { injury. Therefore, the findings } \\
\text { cannot be representative of US } \\
\text { usage in physiotherapy practice } \\
\text { in Australia as a whole. }\end{array}$ \\
\hline $\begin{array}{l}\text { Chipchase and } \\
\text { Trinkle } 2003^{39}\end{array}$ & $\begin{array}{l}\text { Southern } \\
\text { Australia }\end{array}$ & $\begin{array}{l}\text { To determine the } \\
\text { frequency and } \\
\text { trends of use and } \\
\text { effectivenessef US }\end{array}$ & $\begin{array}{l}\text { Rhoysiotherapists } \\
\text { in } \\
\mathrm{N}=380 \text { (public }\end{array}$ & $\begin{array}{l}\text { Postal } \\
\text { Questionnaire } \\
\text { Survey; (55\%, } \\
\mathrm{n}=210 \text { ) }\end{array}$ & $\begin{array}{l}\text { Once/day and an average of } 33 \% \\
( \pm 2) \text { of treatments involved US } \\
\text { therapy. The four most frequently } \\
\text { used EPAs were US, interferential, } \\
\text { CSWD and TENS. Healing of tissues }\end{array}$ & $\begin{array}{l}\text { The response rate was moderate. } \\
\text { The study involved both private } \\
\text { and public sector } \\
\text { physiotherapists but the } \\
\text { breakdown was not reported. }\end{array}$ \\
\hline
\end{tabular}




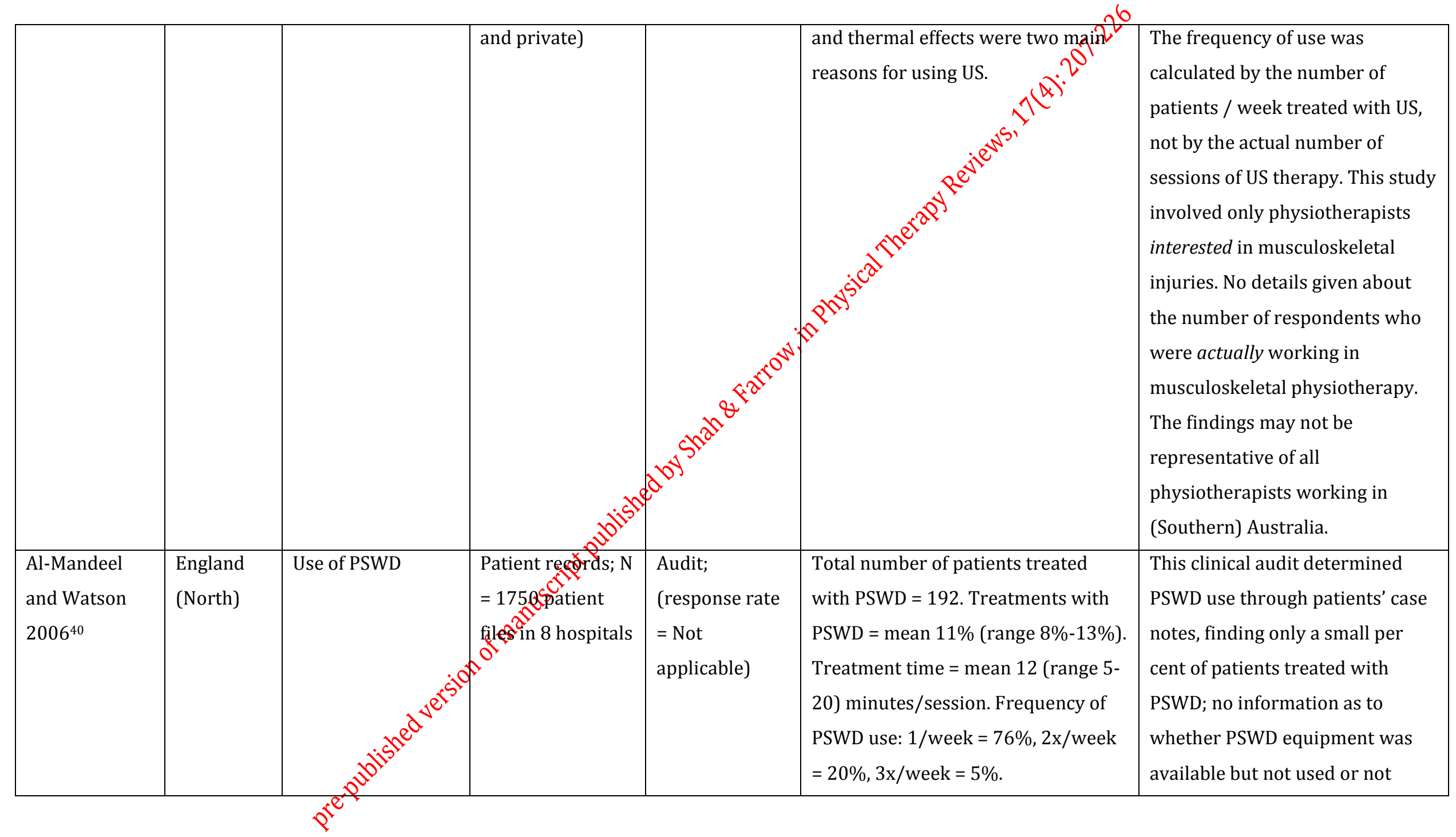




\begin{tabular}{|c|c|c|c|c|c|c|}
\hline & & & & & $\int^{e^{e^{n}}}$ & $\begin{array}{l}\text { available. This audit provided } \\
\text { valuable information on duration } \\
\text { of PSWD treatment although } \\
\text { information was incomplete in } \\
\text { the majority of patient files. }\end{array}$ \\
\hline $\begin{array}{l}\text { Tabasam and } \\
\text { Johnson } \\
2006^{41}\end{array}$ & $\begin{array}{l}\text { England } \\
\text { (North) }\end{array}$ & $\begin{array}{l}\text { Use of } \\
\text { interferential for } \\
\text { pain management }\end{array}$ & $\begin{array}{l}\text { Physiotherapists; } \\
\mathrm{N}=\text { all } \\
\text { physiotherapists } \\
\text { in } 4 \text { hospitals }\end{array}$ & $\begin{array}{l}\text { Postal } \\
\text { Questionnaire } \\
\text { Survey, (Not } \\
\text { stated) }\end{array}$ & $\begin{array}{l}\text { Interferentianse by } 91 \%(\mathrm{n}=57) \text {. } \\
\text { Frequenty of use: } 63 \%(\mathrm{n}=36) \text {, used } \\
\text { for pain relief: } 61 \%(\mathrm{n}=35) \text { of which } \\
\text { clinic patients. Average treatment } \\
\text { time with interferential was between } \\
11 \text { and } 20 \text { minutes. }\end{array}$ & $\begin{array}{l}\text { This small regional study, } \\
\text { involved physiotherapists from } \\
\text { only } 4 \text { hospitals. Neither the } \\
\text { actual sample size nor the } \\
\text { response rate reported. It was the } \\
\text { only study that focused on } \\
\text { interferential use but only in pain } \\
\text { management. The findings on } \\
\text { interferential use very specific } \\
\text { but did not represent overall } \\
\text { pattern of use of this modality. No } \\
\text { details about non-availability and } \\
\text { non-use reported. }\end{array}$ \\
\hline $\begin{array}{l}\text { Shah et al. } \\
2007^{16}\end{array}$ & $\begin{array}{l}\text { England } \\
\text { (Southeast } \\
\text { and } \\
\text { Southwest }\end{array}$ & $\begin{array}{l}\text { The availability } \\
\text { and use of } \\
\text { electrothergasy } \\
\text { equipment }\end{array}$ & $\begin{array}{l}\text { PHS } \\
\text { departments } \\
(\mathrm{N}=46) \text {, random }\end{array}$ & $\begin{array}{l}\text { Postal } \\
\text { Questionnaire } \\
\text { Survey (100\%) }\end{array}$ & $\begin{array}{l}\text { Availability of equipment: US } 100 \% \text {, } \\
\text { PSWD 93.5\%, CSWD } 30.4 \% \text {, laser } \\
\text { 50\%, interferential } 95.7 \% \text {, TENS } \\
82.6 \% \text {, biofeedback } 84.8 \% \text {, MWD 0\% }\end{array}$ & $\begin{array}{l}\text { Response rate excellent but } \\
\text { sample size moderate. Involved } \\
\text { only NHS physiotherapy } \\
\text { departments and clinics located }\end{array}$ \\
\hline
\end{tabular}




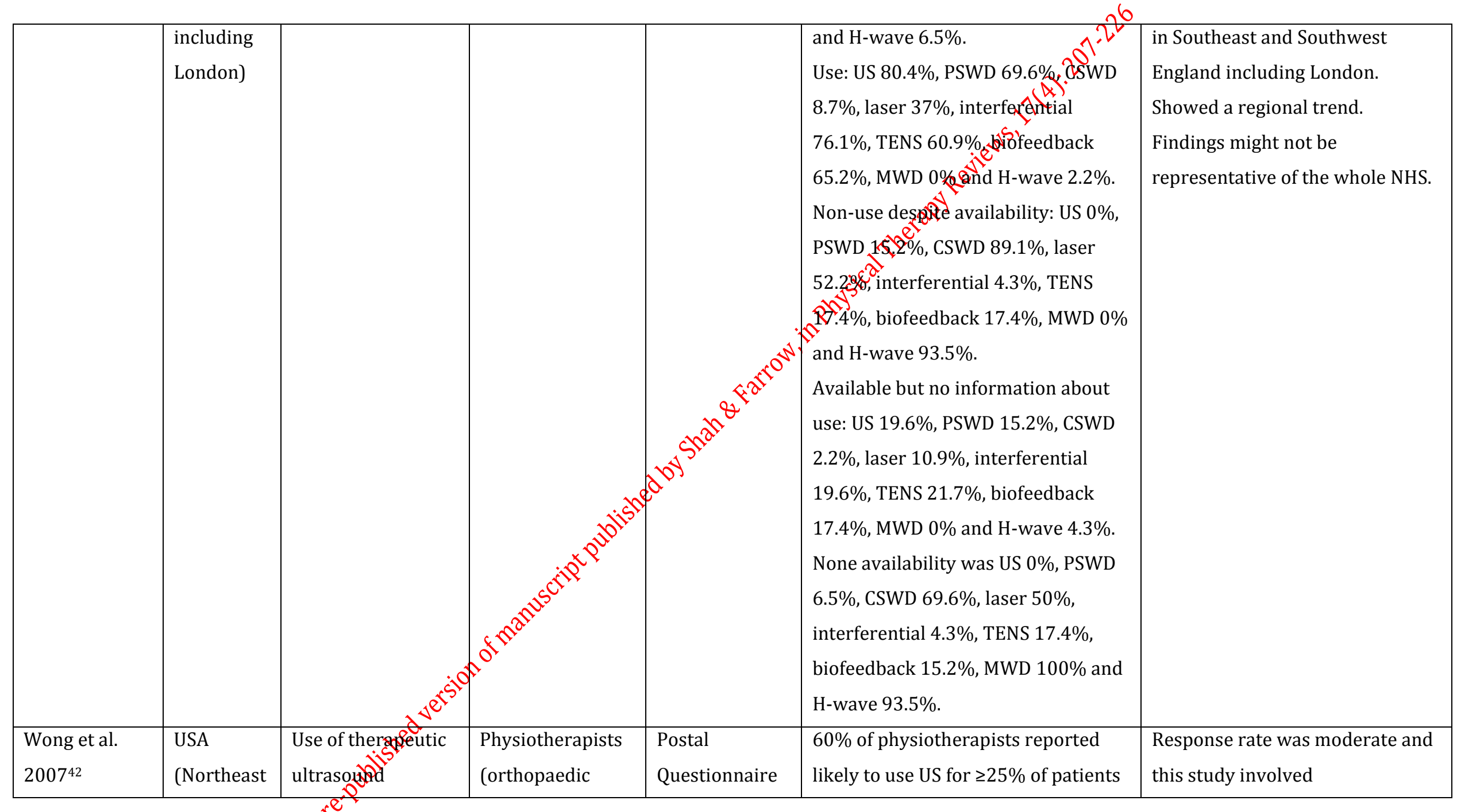




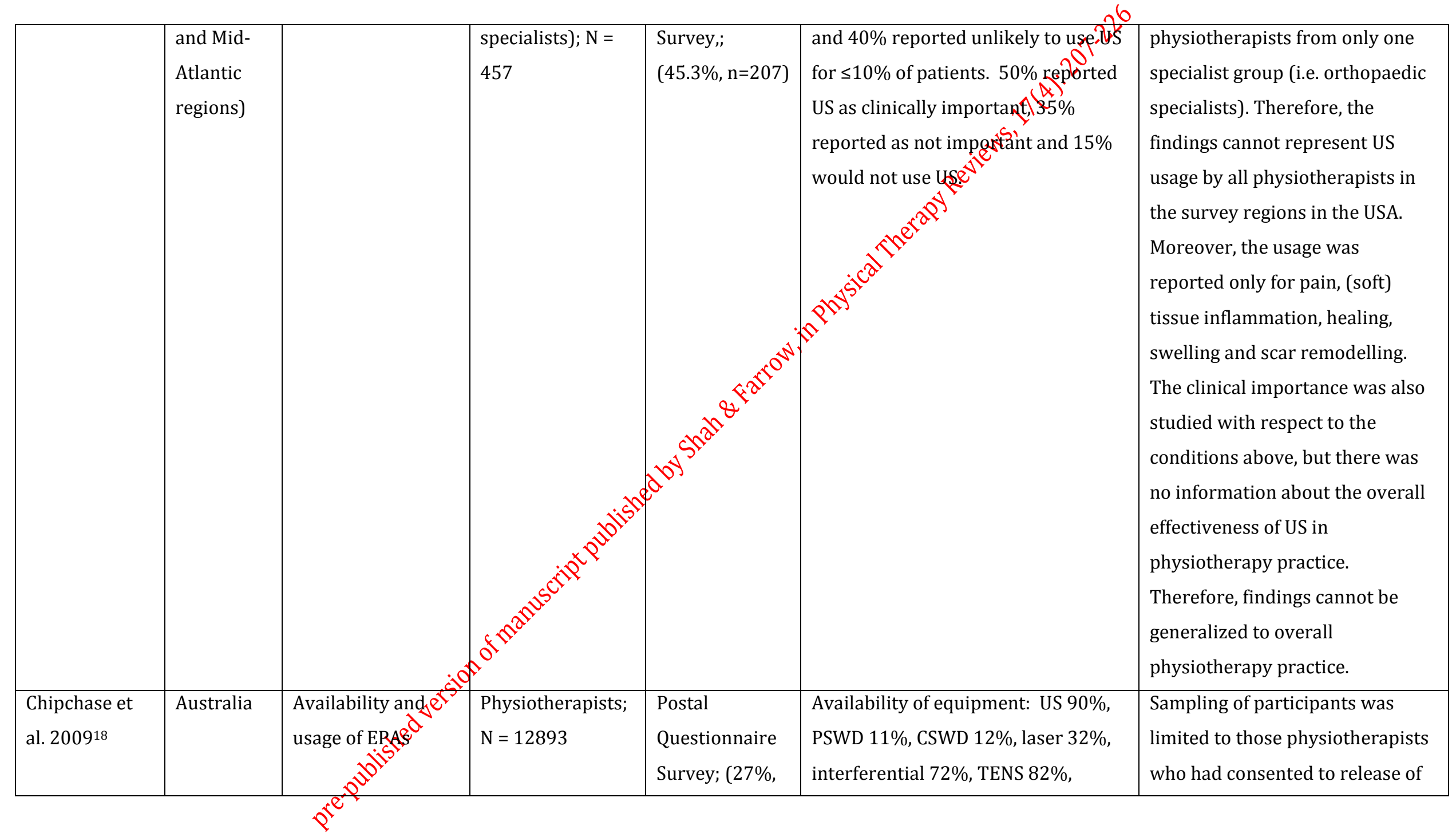




\begin{tabular}{|c|c|c|c|c|c|c|}
\hline & & & & 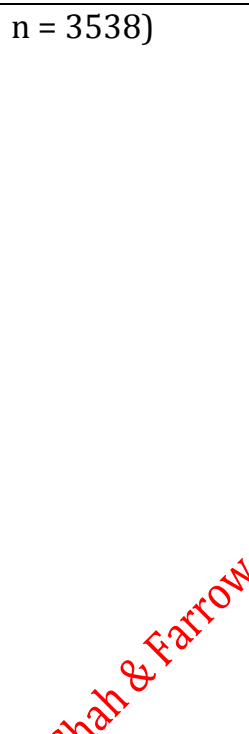 & 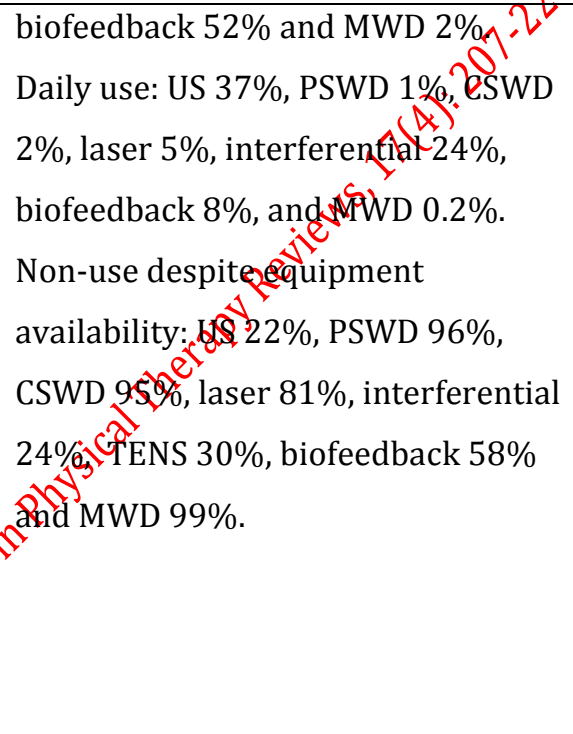 & $\begin{array}{l}\text { their contact details; the response } \\
\text { rate was therefore very low. } \\
\text { Thus, major limitations to the } \\
\text { generalizability of findings } \\
\text { applicable to Australia as a whole. } \\
\text { The study did not cover all } \\
\text { modalities, e.g. H-wave was not } \\
\text { surveyed. No reasons were stated } \\
\text { for non-use despite availability of } \\
\text { equipment and no implications } \\
\text { were discussed for widespread } \\
\text { non-use of available equipment. }\end{array}$ \\
\hline $\begin{array}{l}\text { Scudds et al. } \\
2009^{43}\end{array}$ & $\begin{array}{l}\text { UK and } \\
\text { Hong Kong } \\
\text { (HK) }\end{array}$ & $\begin{array}{l}\text { Use and } \\
\text { effectiveness of } \\
\text { TENS compared to } \\
\text { other EPAs in pain } \\
\text { treatment }\end{array}$ & $\begin{array}{l}\text { Physiotherapists; } \\
\mathrm{N}=1200 \text { (600 } \\
\text { each from the }\end{array}$ & $\begin{array}{l}\text { Postal } \\
\text { Questionnaire } \\
\text { Survey; } \\
\text { (Overall } 34.7 \% \text {, } \\
\text { n=416; UK } \\
=35 \%, n=211 ; \\
\mathrm{HK}=34 \%, \\
n=205 \text { ) }\end{array}$ & $\begin{array}{l}\text { Usage of electrotherapy modalities } \\
\text { for pain management was US } 86 \% \text {, } \\
\text { SWD } 50 \% \text {, laser } 48 \% \text {, interferential } \\
78 \% \text { and TENS } 98 \% \text { in HK and US } \\
72 \% \text {, SWD } 24 \% \text {, laser } 22 \% \text {, } \\
\text { interferential } 64 \% \text { and TENS 79\% in } \\
\text { the UK. }\end{array}$ & $\begin{array}{l}\text { Sample was randomly selected } \\
\text { but response rate was low. The } \\
\text { generalizability of findings } \\
\text { limited due to participants } \\
\text { comprising < } 1 \% \text { of the total } \\
\text { registered physiotherapists in the } \\
\text { UK and only } 9 \% \text { of those in Hong } \\
\text { Kong. The data on the use of EPAs } \\
\text { was presented only in graphical } \\
\text { format: the reviewers' }\end{array}$ \\
\hline
\end{tabular}




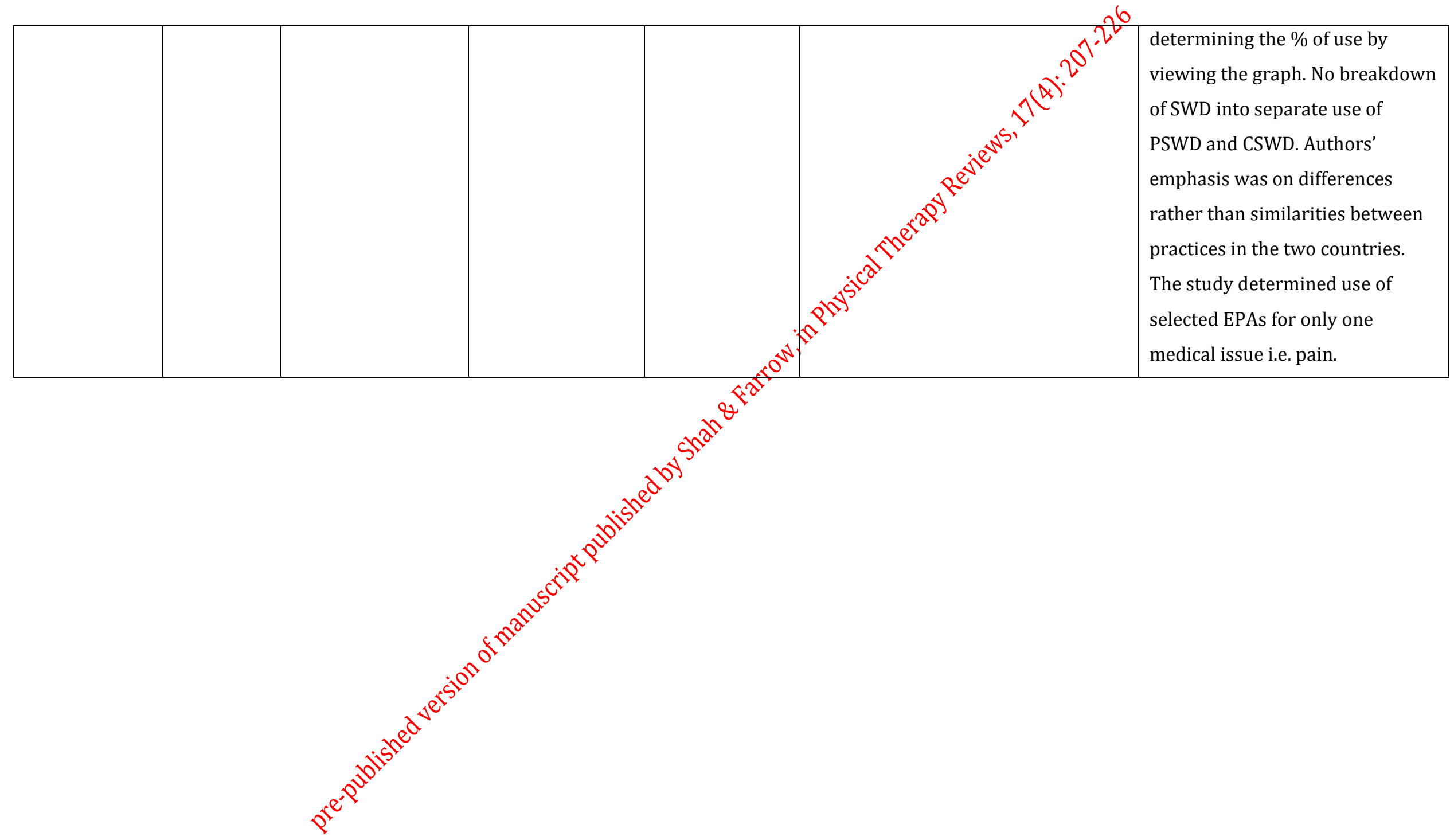




\section{FINDINGS}

The types of electrotherapy modalities that were investigated in 23 studies included in this literature review are shown in Table 2.

The extracted data revealed that $12(52.2 \%)$ studies were published during the 1990s and 11 (47.8\%) studies were published in the 2000s. All of these studies were conducted in English speaking countries: Australia $(n=6)$, Canada $(n=1)$, England ( $\mathrm{n}=8)$, England and Wales (UK) ( $\mathrm{n}=1)$, Hong-Kong and UK (n=1), Northern Ireland (UK) (n=1), Republic of Ireland ( $n=3)$, and the USA (n=2). The identification of studies conducted in only English speaking countries was probably due te selection of language as English. This literature review revealed that most, of these studies were conducted within a regional context such as a study by conducted in Brisbane, Australia; a study by Lindsay et al. ${ }^{29}$ in the province of Alberta, Canada; a study by Seymour and Kerr ${ }^{31}$ in the Trentregion, England; a study by Tabasam and Johnson ${ }^{41}$ in North England and a studys by Wong et al. ${ }^{42}$ in the Northeast and mid-Atlantic regions of the USA.

This literature review found that the 'cross' sectional survey' design with a postal questionnaire was the method mostised. However, Kitchen ${ }^{28}$ used face-toface interviews for their survey and Alsondeel and Watson, ${ }^{40}$ who conducted an audit, reviewed patients' case files the cords to the ox electrotherapy. In the reviewed studies, research participants were physiotherapists; however 2 hysiotherapy departments through their representatives were adsso recruited as participants in some studies. ${ }^{24,33,34,36}$ Most of the studies involyed physiotherapists working in the public sector while a few studies ${ }^{24,29}$ inyolved only private practitioners. Physiotherapists working in both private andrpublic sectors were involved in some studies. ${ }^{28,33,35,36,39}$ In addition, this reviencevealed that some studies involved specialized physiotherapists for paticular clinical conditions. For example, a study by Taylor and Humphry 26

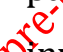
finvolved physiotherapists specialized in physical disabilities; Seymour and Kerr ${ }^{31}$ involved only community physiotherapists; Warden and McMeeken ${ }^{38}$ involved physiotherapists interested in sports injuries; Shields et al. ${ }^{37}$ involved only senior physiotherapists; Chipchase and Trinkle ${ }^{39}$ included physiotherapists interested in the musculoskeletal field and Wong et al. ${ }^{42}$ involved physiotherapists specialized in orthopaedics. Moreover, a few studies investigated the use of electrotherapy in treating particular medical conditions. For example, the use of EPAs in the management of pain was studied by Tabasam and Johnson ${ }^{41}$ and Scudds et al. ${ }^{43}$ 
In the reviewed studies, the sample sizes varied from 10 participants ${ }^{28}$ to a maximum of 12,893 participants. ${ }^{18}$ However, a few studies did not provide the exact sample size. For example, Wong et al..$^{42}$ did not provide any information on their sample size while Lindsay et al. ${ }^{29}$ reported their sample size as 'all private practitioners registered in Alberta, Canada' and did not provide the exact number of the private practitioners. The response rate also varied widely in the reviewed studies from $27 \%{ }^{18}$ to the highest response rate at $99.3 \%{ }^{36}$

The findings of this literature review showed that some studies investigated only one electrotherapy modality such as therapeutic ultrasound studied by Warden and McMeekan, ${ }^{38}$ Chipchase and Trinkle ${ }^{39}$ and Wong et al., ${ }^{42}$ PSWD by Al-Mandeel and Watson, ${ }^{40}$ interferential by Tabasam and Johnson ${ }^{41}$ and laser by Baxtey et al. ${ }^{25}$ and McMeekan and Stillman. ${ }^{27}$ Shields et al. ${ }^{36,37}$ studied two shortwayiemodalities i.e. PSWD and CSWD. The remaining studies investigated more than fyo electrotherapy modalities. Only three studies i.e. Pope et al., ${ }^{23}$ Cooney et al. 35 ğ studied several modalities including US, PSWD, CSWD, MUWD, TENS, interferential, biofeedback, laser and H-wave (Table 2). 
Table 2 Types of electrotherapy modalities investigated in the reviewed studies

\begin{tabular}{|c|c|c|c|c|c|c|c|c|c|c|c|}
\hline Study / Reference & Year & Country / Location & $U S^{*}$ & $P S W D$ & $C S W D$ & Laser & $I F T^{*}$ & TENS & $B F D^{*}$ & $M W D$ & H-wave \\
\hline Lindsay et al. ${ }^{24}$ & 1990 & Australia (Brisbane) & $\checkmark$ & $\checkmark$ & $\checkmark$ & $\checkmark$ & $\checkmark$ & $\checkmark$ & $\checkmark$ & $\checkmark$ & \\
\hline Baxter et al. ${ }^{25}$ & 1991 & Northern Ireland & & & & $\checkmark$ & & & & & \\
\hline Taylor and Humphry ${ }^{26}$ & 1991 & USA & $\checkmark$ & & & & $\checkmark$ & $\checkmark$ & & & \\
\hline McMeeken and Stillman 27 & 1993 & Australia (Victoria) & & & & $\checkmark$ & & & & & \\
\hline Kitchen 28 & 1995 & England & $\checkmark$ & $\checkmark$ & $\checkmark$ & $\checkmark$ & & & & & \\
\hline Lindsay et al. ${ }^{29}$ & 1995 & Canada (Alberta) & $\checkmark$ & $\checkmark$ & $\checkmark$ & & $\checkmark$ & $\checkmark$ & $\sqrt{6}$ & & \\
\hline Pope et al.23 & 1995 & England & $\checkmark$ & $\checkmark$ & $\checkmark$ & $\checkmark$ & $\checkmark$ & $\checkmark 0^{\prime}$ & $\checkmark$ & $\checkmark$ & $\checkmark$ \\
\hline Kitchen and Partridge ${ }^{30}$ & 1996 & England & $\checkmark$ & $\checkmark$ & $\checkmark$ & $\checkmark$ & & & & & \\
\hline Seymour and Kerr ${ }^{31}$ & 1996 & $\begin{array}{l}\text { England (Trent } \\
\text { region) }\end{array}$ & $\checkmark$ & $\checkmark$ & & & & $\checkmark$ & & & \\
\hline Kitchen and Partridge 32 & 1997 & England & $\checkmark$ & $\checkmark$ & $\checkmark$ & $\sqrt{2}$ & & & & & \\
\hline Robertson and Spurritt ${ }^{33}$ & 1998 & Australia & $\checkmark$ & $\checkmark$ & $\checkmark \cdot a^{2}$ & $\checkmark$ & $\checkmark$ & $\checkmark$ & $\checkmark$ & $\checkmark$ & \\
\hline Partridge and Kitchen ${ }^{34}$ & 1999 & England and Wales & $\checkmark$ & $\checkmark$ & & $\checkmark$ & $\checkmark$ & $\checkmark$ & & & \\
\hline Cooney et al..$^{35}$ & 2000 & Republic of Ireland & $\checkmark$ & & $\checkmark$ & $\checkmark$ & $\checkmark$ & $\checkmark$ & $\checkmark$ & $\checkmark$ & $\checkmark$ \\
\hline Shields et al. ${ }^{36}$ & 2001 & Republic of Ireland & 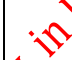 & 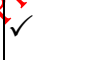 & $\checkmark$ & & & & & & \\
\hline Shields et al. ${ }^{37}$ & 2002 & Republic of Ireland & 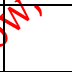 & $\checkmark$ & $\checkmark$ & & & & & & \\
\hline Warden and McMeeken ${ }^{38}$ & 2002 & Australia (Victoriâ) & $\checkmark$ & & & & & & & & \\
\hline Chipchase and Trinkle ${ }^{39}$ & 2003 & Australia (south) & $\checkmark$ & & & & & & & & \\
\hline Al-Mandeel and Watson ${ }^{40}$ & 2006 & England & & $\checkmark$ & & & & & & & \\
\hline Tabasam and Johnson ${ }^{41}$ & 2006 & Ejigland (North) & & & & & $\checkmark$ & & & & \\
\hline Shah et al. ${ }^{16}$ & 20.87 & England (South) & $\checkmark$ & $\checkmark$ & $\checkmark$ & $\checkmark$ & $\checkmark$ & $\checkmark$ & $\checkmark$ & $\checkmark$ & $\checkmark$ \\
\hline Wong et al. ${ }^{42}$ & 2007 & $\begin{array}{l}\text { USA (Northeast/Mid- } \\
\text { Atlantic regions) }\end{array}$ & $\checkmark$ & & & & & & & & \\
\hline Chipchase et al. ${ }^{18}$ of & 2009 & Australia & $\checkmark$ & $\checkmark$ & $\checkmark$ & $\checkmark$ & $\checkmark$ & $\checkmark$ & $\checkmark$ & $\checkmark$ & \\
\hline Scudds et al. ${ }^{43} \mathrm{~s}^{\circ}$ & 2009 & Hong Kong and UK & $\checkmark$ & $\checkmark$ & $\checkmark$ & $\checkmark$ & $\checkmark$ & $\checkmark$ & & & \\
\hline
\end{tabular}

*US = ulty sound, IFT =interferential, $\mathrm{BFD}=$ Biofeedback

The findings of our literature review regarding the trends in the availability and non-availability as well as use and non-use despite availability of nine electrotherapy modalities are presented, in the order of high to low number of studies that investigated these modalities, in the following sub-sections.

\section{Ultrasound (US)}

Ultrasound was the most commonly studied modality in the reviewed literature.

This modality was reported in 17 out of 23 studies (73.9\%) included in this review. 
Four studies $26,38,39,42$ investigated only ultrasound and 13 other studies investigated ultrasound along with other modalities (Table 2). However, not all the studies reported statistics on the variables 'availability', 'use', 'non-use despite availability' and 'non-availability' of this electrotherapy modality. For example, Taylor and Humphry ${ }^{26}$ and Syemour and Kerr ${ }^{31}$ did not report data on the availability and nonavailability whereas Kitchen ${ }^{28}$ did not report data on 'use' and 'non-use despite availability'. In addition, Scudds et al. ${ }^{43}$ did not report statistics on all these four variables and provided data on use of only ultrasound in comparison to other EPAs for pain management. Moreover, Pope et al. ${ }^{23}$ reported the number of physiotherapists ( $n=212$ ) who had access to ultrasound equipment; therefore, we determined by the calculation method explained in the last paragraph of the methods section that the availability of ultrasound was $99.5 \%$ in theikstudy. Data on the availability and use of ultrasound extracted from the reviewed studies showed that the availability of this modality was very high between 190 and 2009; however, the availability of ultrasound started to declinęarore recently (Figure 2). The use of ultrasound was high i.e. between $0 \%$ and $100 \%$ but fitting of a linear trend line showed a declining trend in the of this modality, especially from 2003 to 2009. Non-use despite availability of modality was low but it showed an increasing trend. Similarly, non-availabifoty of this modality was very low from 1990 but it rose to $10 \%$ in 2009 (Figure 


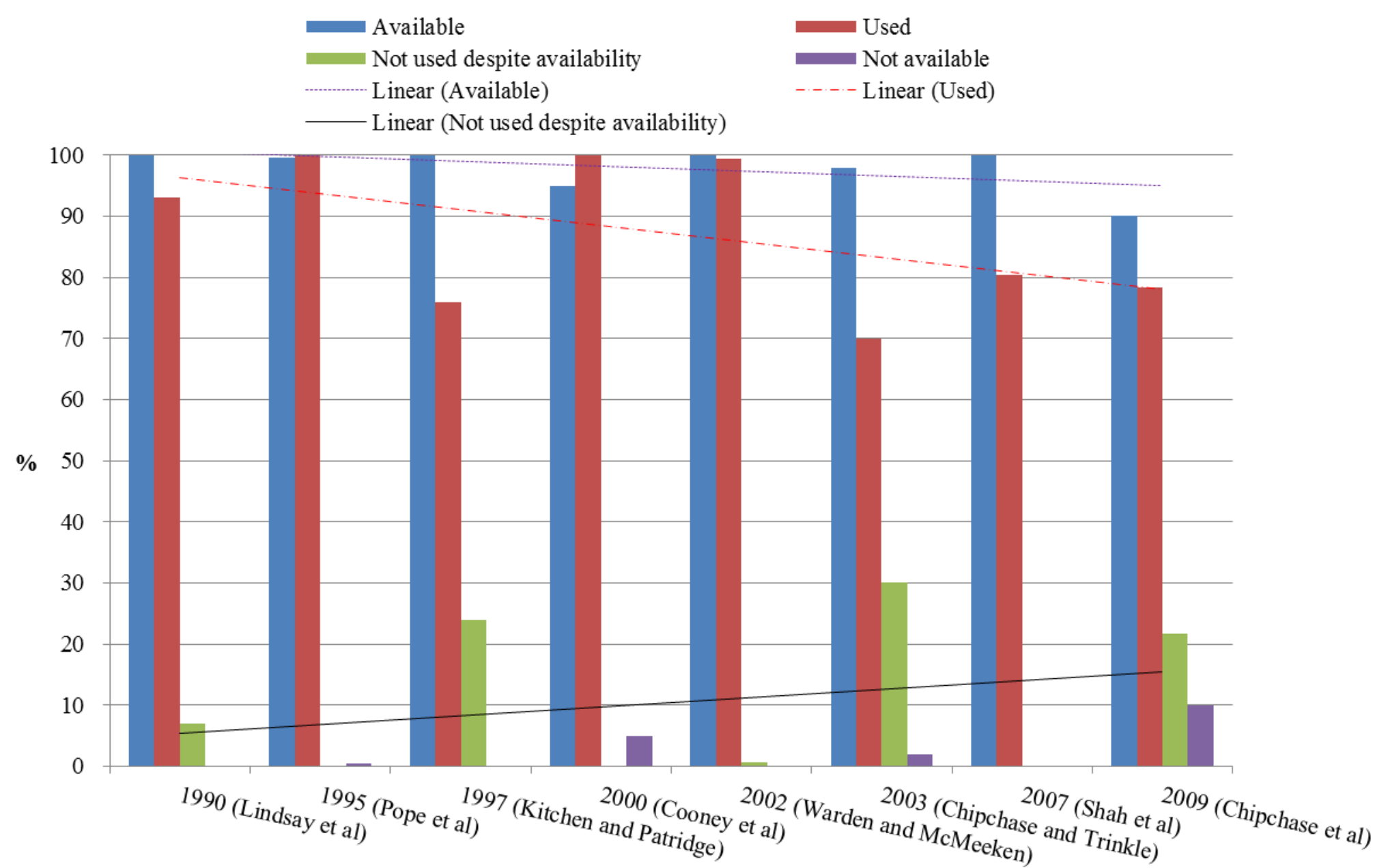

20

Eigure 2 Availability, use, non-use and non-availability of ultrasound (1990 to 2009) $p$ 


\section{Pulsed shortwave diathermy (PSWD)}

Pulsed shortwave diathermy (PSWD) was also one of the most commonly studied electrotherapy modalities in the reviewed literature. This modality was investigated in 16 out of 23 studies (69.6\%) included in this literature review. Study of only PSWD was conducted by Al-Mandeel and Watson ${ }^{40}$, two studies by Shields et al. ${ }^{36,37}$ investigated the PSWD modality along with continuous shortwave diathermy (CSWD) while in the remaining studies $(n=13)$ PSWD was studied in conjunction with other modalities (Table 2). A few of these studies did not report data on all of some of the four variables i.e. 'availability', 'use', 'non-use despite availability and' non-availability' for this modality. For example, study by Lindsay ${ }^{29}$ and Syemour and Kerr ${ }^{31}$ did not report on the four variables above while Kitchen ${ }^{28}$ reporeted data only on the availability of this modality. Scudds et al. ${ }^{43}$ reported data the use but for combined shortwave diathermy (SWD); hence, it was not pessible to extract data for only PSWD from their study. In addition, Pope et al. ${ }^{23}$ reported only the number of physiotherapists $(n=209)$ having access to PSWD eqهi pment. We therefore, calculated that the availability of PSWD was 98.J1 in the study by Pope et al. ${ }^{23}$

Data on the availability and use of PSWD extracted from the reviewed studies (presented in Figure 3) revealed that the availability of this modality was highly variable with highest (>90\%) the lowest availability (11\%) was reported in 2009. The highest (97\%) use of PSWD was reported in 1995 by Pope et al.23; however, the use of this modality started declining afterwards. In 8002 , the use of PSWD was $45 \%{ }^{37}$ and in 2009 , the use of this modality was less than $1 \%$ reported by Chipchase et al. ${ }^{18}$ Fitting of linear trend lines across the ats tracted data on the availability and use of PSWD revealed considerab declining trends in the availability and use of this modality (Figure 3). The non-use despite availability of PSWD varied from 3\% in 1995,23 55\% in 20 Q2837 to $96 \%$ in 2009.18 The non-availability of this modality was fluctuating. In 20 1990, it was 81\%,24 in 1995 it was 2\%,17,23 in 2006 the percentage increased to 6\% and in 2009 it was $89 \% .^{18}$ Linear trend lines fitted across the non-use despite availability and the non-availability data for this modality showed a rising trend for both of these parameters of PSWD (Figure 3). 


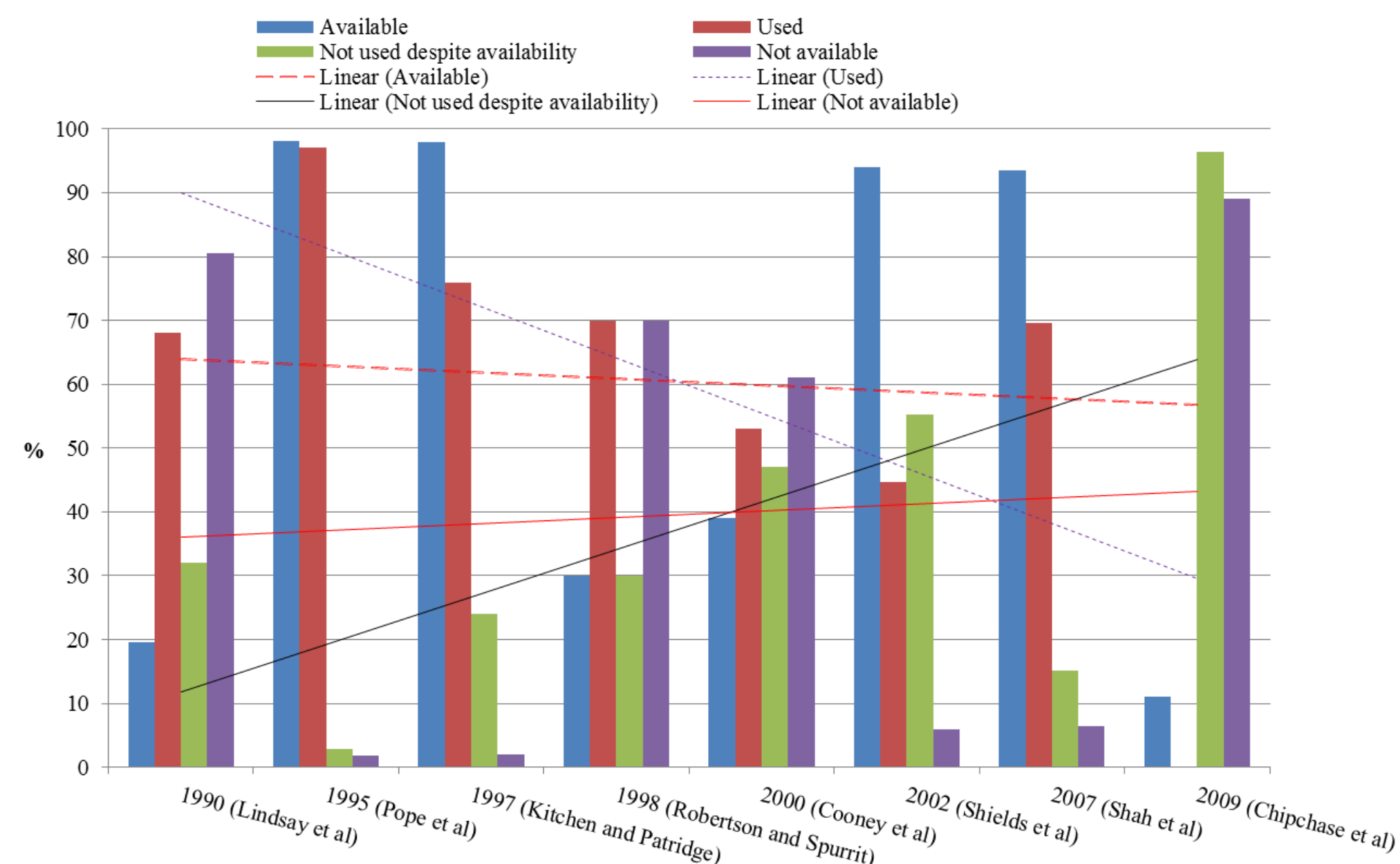

s

$\rho^{2}$ (Higure 3 Availability, use, non-use and non-availability of PSWD (1990 to 2009) 


\section{Continuous shortwave diathermy (CSWD)}

Continuous shortwave diathermy was another commonly studied electrotherapy modalities in the reviewed literature. CSWD was not studied as a single modality in any of the studies included in this review. However, CSWD was studied in conjunction with other modalities (Table 2). This modality was investigated in 14 out of the 23 studies (60.9\%). This indicated that the number of studies of CSWD was lower than the number of studies that investigated ultrasound and PSWD (Table 2). It is also important to point out that a few studies did not provide dataoón the 'availability', 'use', 'non-use despite availability' and 'non-availability' of thisì modality. For example, a study by Lindsay ${ }^{29}$ did not report extractable dáta on all of the above four variables with respect to CSWD. Kitchen ${ }^{28}$ did not report data on 'use' and 'non-use' of CSWD despite equipment availability. Scudds etât.43 reported data on the use of combined shortwave diathermy; therefore, extion of data for only CSWD was not possible from their study. As mentioned etarlier, Pope et al. ${ }^{23}$ reported only the number of physiotherapists $(n=196)$ having access to CSWD equipment. As mentioned earlier, we therefore calculated the availability of CSWD as $85 \%$ in the study by Pope et al.23

Data on the availability and use studies (shown in Figure 4) revealed that the availability of this modality was very high i.e. about $85 \%$ during $19855^{3}$ and $93 \%$ in $2002^{37}$ while the lowest availability (12\%) was reported in 200918 The use of CSWD fluctuated considerably between 1990 and 2009. The hiffiest use (86\%) of CSWD was reported in 1998 by Robertson and Spurritt, ${ }^{33}$ which declined to $56 \%$ in $2002^{37}$ and reached the lowest level (5\%) in $2009 .{ }^{18}$ Fittiog of linear trend lines across the data on the availability and use of CSWD reverled considerable declining trends in both the availability and the use of this molity.

'Non-use despite availability' of this modality varied from $14 \%$ in $1998^{33}$ to P4\% in $2002^{37}$ to $95 \%$ in 2009.18 'Non-availability' of CSWD was lowest (7\%) in $2002^{37}$ but it increased to $88 \%$ in 2009.18 Linear trend lines fitted across the 'nonuse despite availability' and the 'non-availability' data for CSWD showed a rising trend for both these parameters for this modality (Figure 4). 
Available

Not used despite availability

-.-.-.-.-. Linear (Available)

_ Linear (Not used despite availability)
Used

Not available

----- Linear (Used)

Linear (Not available)
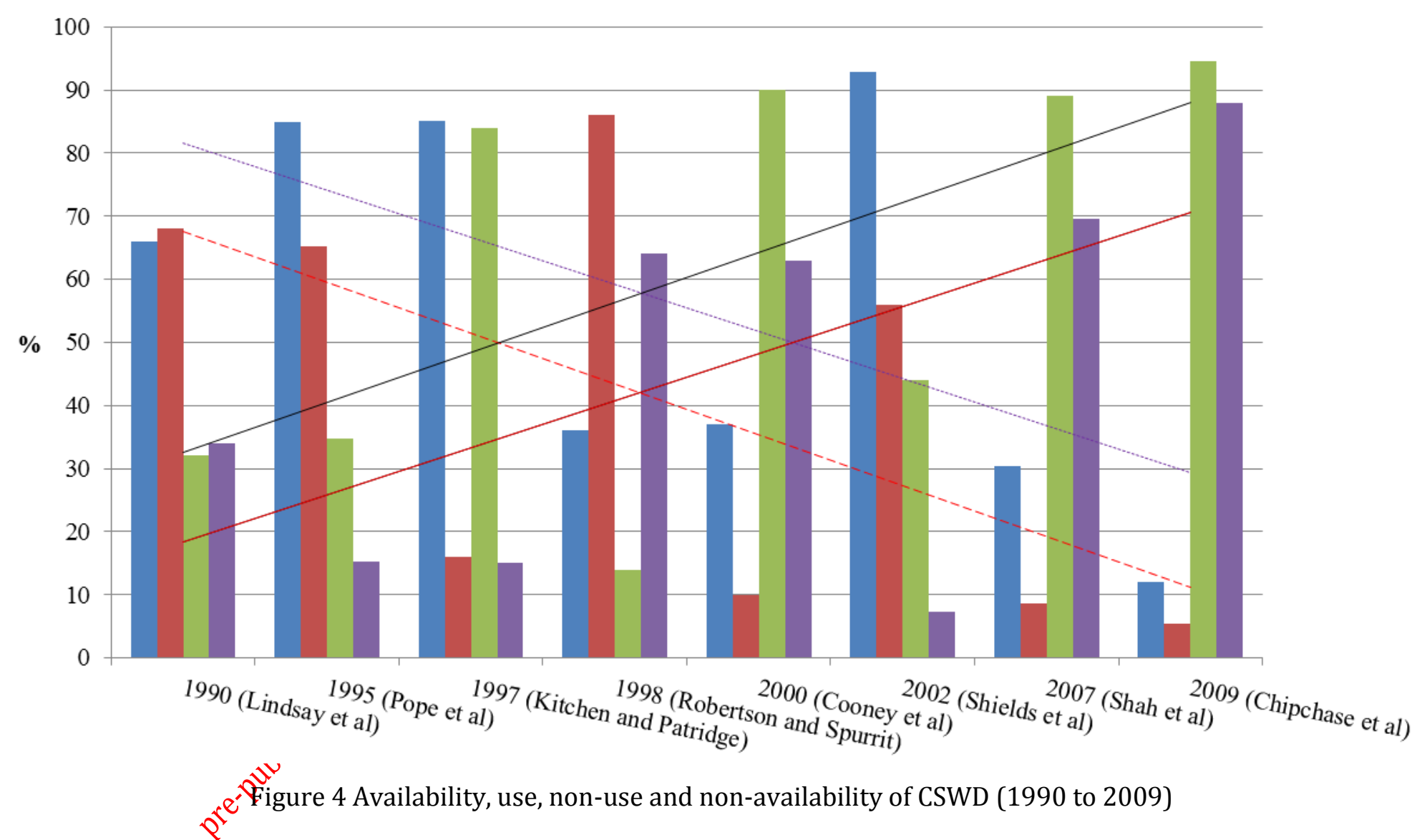


\section{Laser}

Therapeutic laser was also one of the most commonly studied modalities in the reviewed literature. This modality was investigated in 13 out of 23 studies (56.5\%) included in this literature review. Two studies ${ }^{25,27}$ investigated only laser while the remaining 11 studies investigated laser along with other electrotherapy modalities (Table 2). Nevertheless, the data for laser on all or some of the four variables (i.e. 'availability', 'use', 'non-use despite availability' and 'non-availability') were not provided in some of these studies. For example, studies by Baxter et al..$^{25}$ and McMeeken and Stillman ${ }^{27}$ did not report extractable data on the above four variablés with respect to laser. A study by Kitchen ${ }^{28}$ reported data only on the availabiliny of this modality but did not report data on the other three variables. Partridge and Kitchen ${ }^{34}$ reported data on the 'use' and 'non-use' of laser but they dia 'hot report data on the 'availability' and 'non-availability'. As reported earlien regarding the study by Pope et al., ${ }^{23}$ we determined the availability of lasereso be $84.8 \%$. Data on the 'availability', 'use', 'non-use despite availability' and 'son-availability' of laser extracted from the reviewed studies (shown in Figure 5 ) indicated that the availability of this modality was highest (92\%). in 1995.23 However, it declined in the subsequent years. Therefore, the availability of this modality showed an overall declining trend (Figure 5).

The use of laser increased from 58\% in $1990^{24}$ to $100 \%$ in $1998 .{ }^{33}$ However, its use decreased to $59 \%$ in $200 \% 5$ and reached the lowest level of $19 \%$ in 2009.18 Therefore, the use of laser aperall showed a steady increasing trend from 1990 to 2000; however, data showed a slightly declining trend for laser use after 2000 (Figure 5). 'Non-use of laser despite availability' of equipment was 42\% in $1990^{24}$ but declined to $1 \%$ in 1998.33 However, it increased to $41 \%$ in 200035 , almost doubling to $681 \%$ in 2009.18 Consequently, the data for the 'non-use despite laser equipment availability' showed an increasing trend (Figure 5). The non-availability of aser fluctuated in the last twenty years; however, the data extracted from the previewed studies revealed overall a slowly rising trend in the 'non-availability' of this modality (Figure 5). 


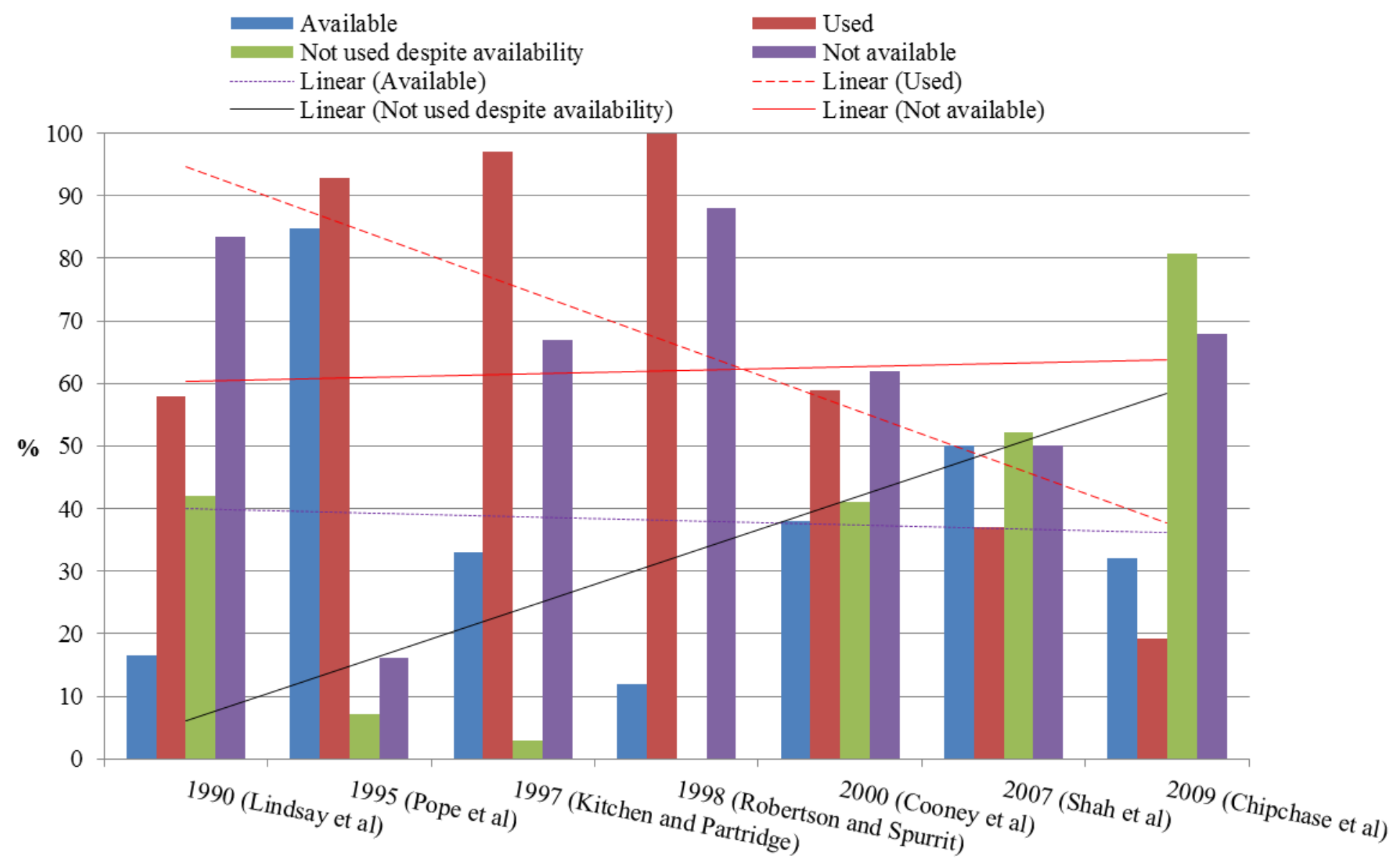

ory

fure 5 Availability, use, non-use and non-availability of laser (1990 to 2009)

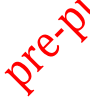




\section{Interferential}

This literature review revealed that interferential modality was also one of the commonly studied electrotherapy modalities. This modality was investigated in 12 out of 23 studies (52.2\%) included in this review (Table 2). A study by Tabasam and Johnson ${ }^{41}$ studied only this modality while the remaining ten studies studied interferential along with other modalities (Table 2). It is important to point out that Tabasam and Johnson ${ }^{41}$ studied treatment with interferential by auditing / reviewing patients' case files and they did not report statistics on the 'availability', 'use', 'non-use' and 'non-availability' of equipment with respect to this modality isi physiotherapy departments. In addition, Taylor and Humphry ${ }^{26}$ and Seymounand Kerr ${ }^{31}$ reported data on the 'use' and 'non-use' of interferential but they gुid not report data on the overall 'availability' and 'non-availability' of this modality. Two further studies ${ }^{29,34}$ also did not report extractable data with respect to this modality. Pope et al. ${ }^{23}$ reported the total number of physiotherapists (207) having access to interferential equipment and from this figure we determiche equipment availability of this modality to be $97 \%$ in the study bi Pope et al. ${ }^{23}$

Data on the' availability', 'use', 'non-use' ath 'non-availability' of interferential extracted from the reviewed stipdies (presented in Figure 6) showed a slightly declining trend of the availabilitive and use of interferential modality. Although the use of this modality imareased from $90 \%$ in 1990 to $100 \%$ in 2000, it declined by about $25 \%$ in 2009 sompared to 2000 (Figure 6). The lowest use of this modality was $66 \%$ in 1998 \% The 'non-use' of interferential was highest (about $35 \%$ ) in $1998^{33}$ while thêe 'non-use' of this modality was reported zero by Cooney et al. in $2000^{35}$ and Sha et al. ${ }^{16}$ However, the 'non-use' of interferential again increased to $24 \% 0$ in 2009.18 Similarly, the 'non-availability' of interferential equipmenteras $15 \%$ in $1990^{24}$, and decreased to $2 \%$ in $2000^{35}$ but it increased again and regethed 28\% in 2009.18 Therefore, the 'non-availability' of interferential equipment revealed an overall increasing trend (Figure 6). 


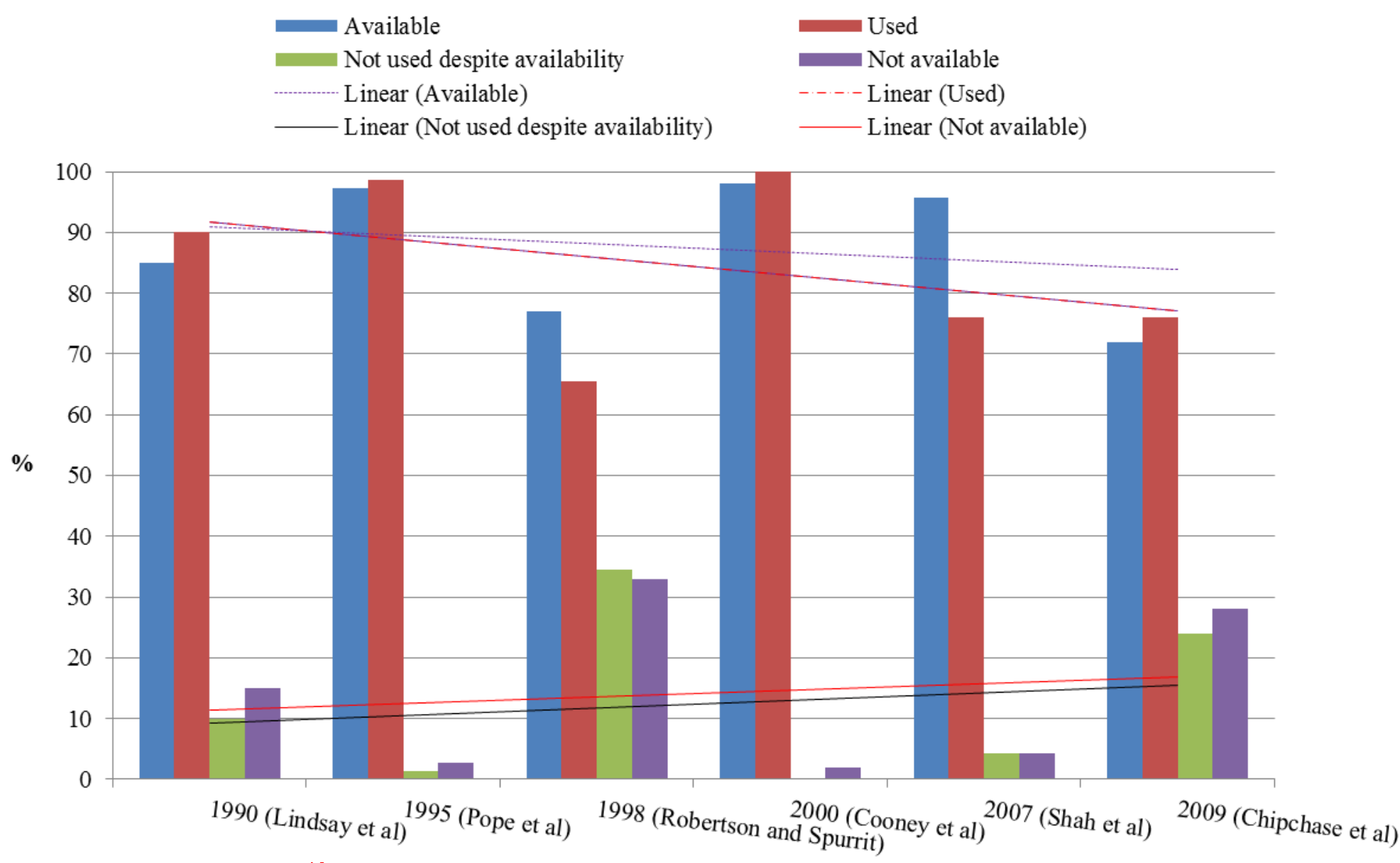

Figure Availability, use, non-use and non-availability of interferential (1990 to 2009)

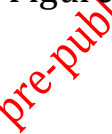




\section{Transcutaneous electrical nerve stimulation (TENS)}

Transcutaneous electrical nerve stimulation was one of the commonly studied electrotherapy modalities in the reviewed literature. This modality was studied in 11 out of 23 studies (47.8\%) included in this review (Table 2). Taylor and Humphry ${ }^{26}$ studied only TENS while the other ten studies investigated TENS along with other modalities (Table 2). Three studies ${ }^{26,31,34}$ reported data on the 'use' and 'non-use' of TENS but they did not report data on the overall 'availability' and 'nonavailability' of this modality. A study by Lindsay et al. ${ }^{29}$ did not report extractable data with respect to this modality. As mentioned earlier, we determined the availability of this modality as $98.1 \%$ in the study by Pope et al. ${ }^{23}$ The statistiosion the 'availability', 'use', 'non-use' and 'non-availability' of TENS extracted from the reviewed studies revealed that the availability of TENS equipment presented a slightly declining trend (Figure 7).

The use of this modality showed an increasing trend 1990 to 2000; however, the use of this modality decreased by about $30 x$ in 2009 compared to 2000 (Figure 7). In addition, there was a declining trond in the 'non-use despite availability' of TENS; thus, the 'non-availability' è auipment of this modality suggested overall a slightly increasing trend 


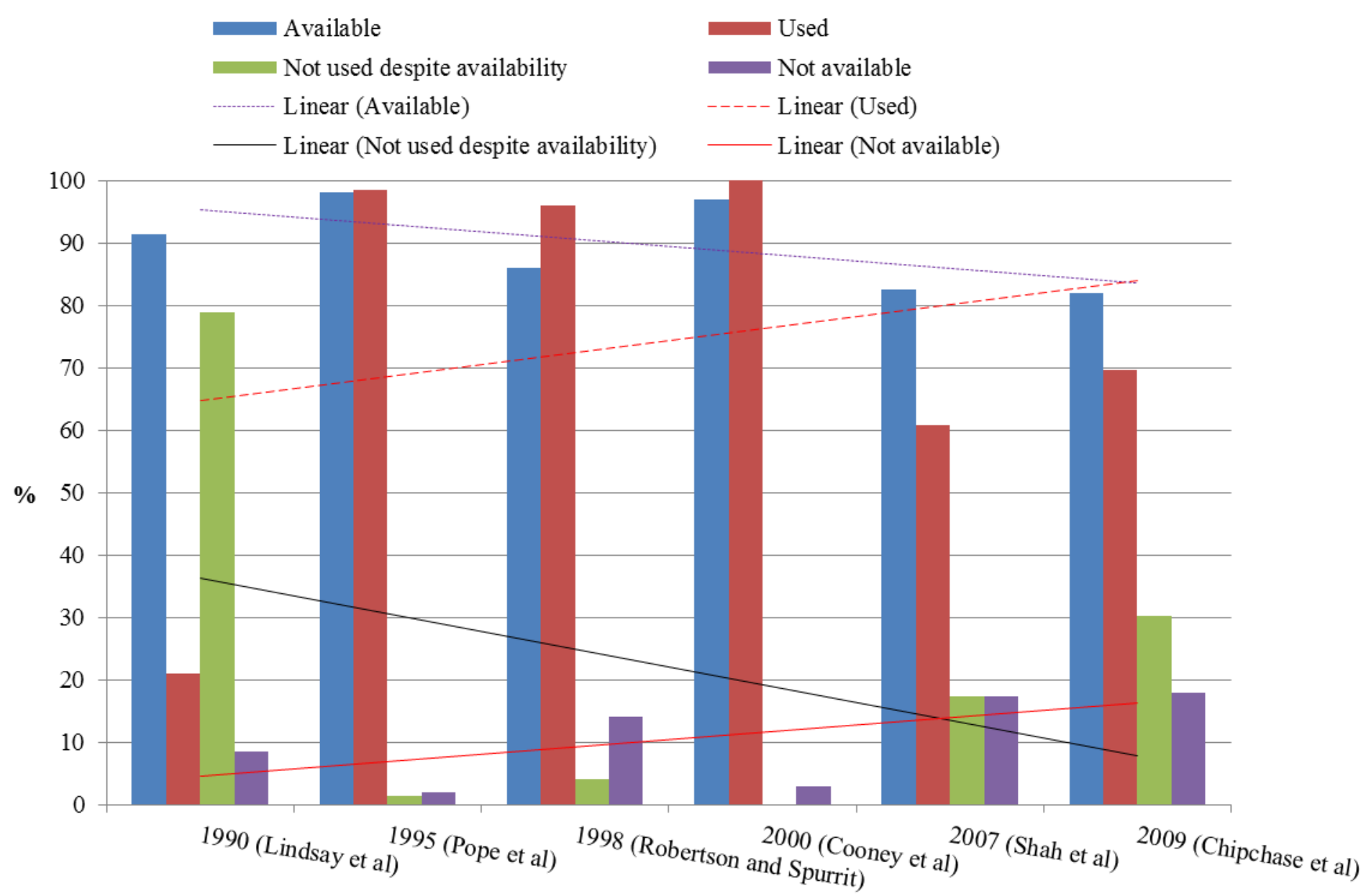

cy

Evisure 7 Availability, use, non-use and non-availability of TENS (1990 to 2009)

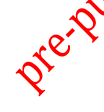




\section{Biofeedback}

This literature review showed that the biofeedback modality was one of the less commonly studied electrotherapy modalities in the reviewed studies (Table 2). Biofeedback was investigated in seven out of 23 studies (30.4\%) included in this review (Table 2). In these seven studies, biofeedback was investigated in association with other modalities (Table 2.2). Lindsay et al. ${ }^{29}$ did not report extractable data with respect to this modality. Two studies ${ }^{33,35}$ did not report data on the 'availability' and 'non-availability' of biofeedback equipment; however, they presented data on the 'use' and 'non-use' of this modality. In addition, Pope et al? 23 also did not report data with respect to the overall availability of this modality. Therefore, the availability of this modality was determined by us as $8.388_{0}^{\text {S }}$ in the study by Pope et al. ${ }^{23}$ Data on the 'availability', 'use', 'non-use' and Ron-availability' of interferential extracted from the reviewed studies are preserited in Table 3.

Table 3 Availability, use, non-use and non-availability of Biofeedback (1990-2009)

\begin{tabular}{|c|c|c|c|c|}
\hline Year (Study) & $\begin{array}{l}\text { Available } \\
(\%)\end{array}$ & $\begin{array}{l}\text { Used } \\
\text { oid } \\
\text { (\%) }\end{array}$ & $\begin{array}{l}\text { Not used despite } \\
\text { availability (\%) }\end{array}$ & $\begin{array}{l}\text { Not available } \\
(\%)\end{array}$ \\
\hline 1990 (Lindsay et al) $^{24}$ & $24 y^{x}$ & 18 & 83 & 77 \\
\hline 1995 (Pope et al) ${ }^{23}$ & $835 h^{2}$ & 94 & 6 & 17 \\
\hline 1998 (Robertson and Spurrit) ${ }^{33}$ & 2 & NA & NA & 68 \\
\hline 2000 (Cooney et al) $^{35}$ & 3 & NA & NA & 97 \\
\hline 2007 (Shah et al) ${ }^{16}$ & 84.8 & 65.2 & 17.4 & 15.2 \\
\hline 2009 (Chipchase et al) ${ }_{5}^{18} \mathrm{c}^{2}$ & 52 & 43 & 58 & 48 \\
\hline
\end{tabular}

The extracted data (Table 3) showed that the availability of biofeedback fluctuated between 1990 and 2009. In 1995, Pope et al. ${ }^{23}$ reported availability of biofeed 18 ack as $83 \%$ which declined to the lowest level of 3\% in 2000 as reported by Coovey et al. ${ }^{35}$ However, the availability of this modality increased in the later years (e po $85 \%$ reported by Shah et al. ${ }^{16}$ and it declined once again to $52 \%$ in 2009 as reported by Chipchase et al. ${ }^{18}$ The use of this modality was lowest (18\%) in $1990^{24}$ and highest (94\%) in 1995. ${ }^{23}$ However, the use of this modality decreased and reached about $43 \%$ in $2009 .{ }^{18}$ The 'non-use' of biofeedback was highest (83\%) in $1990^{24}$ and lowest (2.2\%) in 2007.16 However, it increased to 58\% in 2009.18 The 'non-availability' of biofeedback equipment was highest (97\%) in $2000^{35}$ but it declined to the lowest of $15.2 \%$ in 2007.16 Overall, the 'availability' and 'nonavailability' of this modality fluctuated in the reviewed studies. 


\section{Microwave diathermy (MWD)}

Microwave diathermy was also a less commonly studied electrotherapy modality in the reviewed literature. This modality was investigated in only six (26.1\%) out of 23 studies included in this review. MWD was not studied as a single modality in any of the 23 studies included in this review but was studied along with other electrotherapy modalities (Table 2). As reported earlier, we calculated the availability of MWD as $83.6 \%$ in the study by Pope et al. ${ }^{23}$ In addition, Cooney et al. ${ }^{35}$ reported use of MWD as the 'least used' but did not report any statistics on the 'non?t' use despite availability' of MWD equipment. A later study by Shah et al. ${ }^{16}$ condueted in southeast and southwest of England showed that MWD was not available

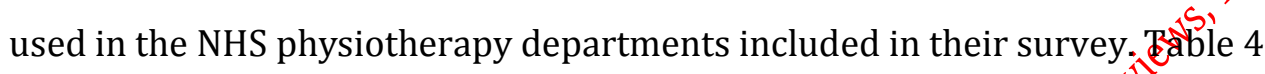
presents the statistics on the 'availability', 'use', 'non-use' and 'non oavailability' of MWD extracted from the reviewed studies.

The findings showed that the availability of this modality was highest (84\%) in $1995^{23}$ and decreased considerably to $6 \%$ in 20003 tolling to the lowest level (2\%) in 2009.18 The 'use' of MWD was between 64\% and 79\% from 1990 to 1998; however, it declined to very low use from 2000 to none in 2007. Similarly, the 'nonavailability' of MWD was higher ranging $67 \%$ in $1990^{24}$ to $93 \%$ in $1998^{33}$ and $100 \%$ in 2007. ${ }^{16}$ However the lowest whon-use' of MWD (21\%) despite equipment availability was reported by Popect al. in 1995.23 The greater difference in the 'nonavailability' of MWD might bestue to the differences in the location of studies. For example, the Pope et al. $\$ y^{23}$ was conducted in England while other studies on MWD were conducted in Australia18,24,33and in the Republic of Ireland 35 as shown in Table 2. The dataon MWD presented in Table 4 revealed that the overall availability and use of thas modality showed a declining trend while the 'non-use' and 'nonavailability' presented an increasing trend in the reviewed studies.

T娧Ble 4 Availability, use, non-use and non-availability of MWD (1990-2009)

\begin{tabular}{lllll}
\hline Year (Study) & $\begin{array}{l}\text { Available } \\
(\%)\end{array}$ & Used (\%) & $\begin{array}{l}\text { Not used despite } \\
\text { availability (\%) }\end{array}$ & $\begin{array}{l}\text { Not available } \\
(\%)\end{array}$ \\
\hline 1990 (Lindsay et al) $^{24}$ & 33 & 79 & 21 & 67 \\
1995 (Pope et al) $^{23}$ & 84 & 64 & 36 & 16 \\
1998 (Robertson and Spurritt) $^{33}$ & 7 & 75 & 25 & 93 \\
2000 (Cooney et al) $^{35}$ & 6 & Least used & Not reported & 94 \\
2007 (Shah et al) $^{16}$ & 0 & 0 & 0 & 100 \\
2009 (Chipchase et al) $^{18}$ & 2 & 0.6 & 99 & 98 \\
\hline
\end{tabular}




\section{H-wave}

$\mathrm{H}$-wave was the least studied modality in the reviewed literature. It was investigated in only $13 \%$ i.e. three of the 23 studies included in this review (Table 2). Data extracted from these studies on the 'availability', 'use', 'non-use despite availability' and 'non-availability' of equipment is presented in Table 5.

The findings showed that the availability and use of $\mathrm{H}$-wave was highest in $1995 .{ }^{23}$ However its lowest availability was $2 \%$ in $2000^{35}$ and the lowest use was $34 \%$ in $2007 .{ }^{16}$ There were no data on the 'use' and 'non-use despite availability' of 2 this modality reported in the study by Cooney et al. ${ }^{35}$ The highest non-availability of this modality was $98 \%$ in $2000^{35}$ but it declined to $93.5 \%$ in 2007.16 Overa 11, the reviewed literature showed that the availability of $\mathrm{H}$-wave was at the 60 rge of disappearing and its non-availability in physiotherapy departmenes was becoming widespread from 2000 onwards.

Table 5 Availability, use, non-use and non-availabilituof H-wave (1995-2007)

\begin{tabular}{|c|c|c|c|c|}
\hline Year (Study) & $\begin{array}{l}\text { Available } \\
(\%)\end{array}$ & Used & $\begin{array}{l}\text { Not used despite } \\
\text { availability (\%) }\end{array}$ & Not available (\%) \\
\hline 1995 (Pope et al) 23 & 82 & $97 x^{y}$ & 3 & 18 \\
\hline 2000 (Cooney et al) $)^{35}$ & 2 & Aot reported & Not reported & 98 \\
\hline 2007 (Shah et al) ${ }^{16}$ & 6.5 & 8 & 0 & 93.5 \\
\hline
\end{tabular}

\section{DISCUSSION}

This literaturefeview comprised a review of 23 studies. Our detailed comments on each of the studies included in this literature review are given in Table 1. Overall, we foum $\mathrm{j}_{\mathrm{c}}$ hat most of the studies were conducted on a regional level with a small sample size; hence, the findings of these studies have limited generalizability. In addition, reporting of the data in these studies varied; therefore, it was difficult to extract the required data on the same parameters from all of the studies.

Our findings of the present literature review show overall patterns in the availability and usage of nine electrotherapy modalities as follows. Therapeutic ultrasound was the most available ( $90 \%$ to $100 \%$ ) and used (70\% to $100 \%$ ) since 1990 . The reasons for widespread use of ultrasound could be the ease of application and portability. ${ }^{24}$ However, ultrasound non-use despite availability has increased recently, especially 
in Australia $(22 \%)^{18}$ and there are calls for trials to study clinical effectiveness of ultrasound. ${ }^{39,42,44}$

Our findings show that PSWD availability and usage is high in the UK and the Republic of Ireland but low in Australia. The non-use of PSWD despite equipment availability is low in England compared to the Republic of Ireland and Australia. Overall, the non-use of PSWD despite availability of equipment has greatly increased in the recent years, especially in Australia (96\%) ${ }^{18}$ where it is mostly non-available $(89 \%)^{18}$. CSWD shows a declining trend in availability and use while its nonavailability and non-use despite equipment ownership shows rising trends, which might be due to safety concerns. ${ }^{44-46}$

For laser, availability is slightly decreasing, and use shows a substantial declining trend while its non-availability and non-use despite availability shows increasing trends. Interferential shows a steady but declining trengd' in availability and use; however, its non-availability and non-use despite equipment ownership show slightly rising trends, especially in Australia. Also, there is demand for more research on clinical effectiveness of interferential. 35 rends for TENS show a low decline in availability and non-use despite ownenship; however, its use and nonavailability show moderately increasing trents. The non-use of this modality is higher in Australia compared to the UK effectiveness of TENS has been suggessted. $43,45,46$ Biofeedback is highly available and used in England compared to ingunstralia and the Republic of Ireland where this modality was mostly non-avatlable during the review period. The non-use of this modality is the highest it Australia.

Our review has revealed that MWD availability and use show a very steep 4

decline from 1990 to 2009 while its non-availability and non-use despite equipment ownership the highest of all electrotherapy modalities included in this review. In addition, we found greater differences in the degree of 'non-availability' of MWD in the reviewed studies, which might be due to the differences in the location of in studies. For example, the Pope et al. study ${ }^{23}$ was conducted in England while other studies on MWD were conducted in Australia18, 24, 33 and in the Republic of Ireland ${ }^{35}$ as shown in Table 2. It is also imperative to note that only one study i.e. Shah et al.16 reported 100\% non-availability hence non-use of this modality in England. The main reasons for widespread non-use of MWD may be safety concerns for patients ${ }^{34}$ and physiotherapists ${ }^{4-46}$ and supersession of this modality. ${ }^{35}$

Trends in the availability and the use of $\mathrm{H}$-wave showed a great decline while its non-availability was found steeply increasing during the last two decades. 
The main reasons for widespread non-use of this modality might be due to its supersession..$^{35}$

In summary, our findings suggest that electrotherapy modalities studied in this review can be divided in four categories. The first category includes the most commonly available and used modalities that are ultrasound, interferential, TENS and biofeedback. The second category comprises frequently available and used modalities that include PSWD and laser. The third category consists of CSWD, which is a rarely used modality. The fourth (last) category contains MWD and H-wave, which are very rarely used electrotherapy modalities and they are at the verge of disappearance from physiotherapy practice.

This literature review has also revealed that there have been differences in the availability and usage of electrophysical agents in physiotherapy posactices in the last twenty years. These differences varied between electrotheray modalities, between countries, between public and private physiotheraperactices, and between the years of the studies. Differences in the use and availability of EPAs might be determined by differences in these countri@in terms of electrotherapy education and training, ${ }^{43}$ and the nature of clinigat practices. ${ }^{35,43}$ In addition, use of electrotherapy is determined by several facters such as the equipment availability, ${ }^{30}$ ${ }^{44}$ reputation of being safe, such as for ulicasound and TENS, 24, 47, 48 physiotherapists' experience and belief about effects the modality, ${ }^{49}$ the clinical effectiveness ${ }^{50}$ the type of medical condition ${ }^{30,49}$ and the nature of physiotherapy practices. $16,24,27$ Overall, the emerging trend of electrotherapy revealed in this review is that the use of these EPAs is declining and their non-availability is rising, which may be due to several reasons (Tabore 6). The most common reasons for non-use of EPAs include lack of evidence for clinical effectiveness, non-availability of equipment, safety concerns, arid lack of knowledge / familiarity with and training in using these electrotherapy modalities.

In addition, the non-use and non-availability of these modalities might have implications for their purchasers, users (clinicians and patients) as well as manufacturers and suppliers. Non-use despite equipment availability for some of these modalities is a waste of resources for the purchasers of this costly equipment. ${ }^{16}$ 
Table 6 Reasons for non-use of electrophysical agents in physiotherapy practices

\begin{tabular}{ll}
\hline Reasons for non-use & References \\
\hline Non-availability of equipment & $17,30,44$ \\
Safety concerns / fear of safety & $11,24,33,47$ \\
Lack of evidence for clinical effectiveness & $11,27,28,33,35-37,43,50-52$ \\
Physiotherapist's choice & 23,15 \\
Lack of knowledge / training and unfamiliarity with the modality & $23,35,52,53$ \\
Lack of research and information on EPAs & 25,27 \\
Nature of the clinical condition being treated & 30 \\
Supersession of modality e.g. MWD and H-wave & 35 \\
Level of ease of / difficulty in application & 24 \\
Area / nature of practice i.e. private vs. public sector use, and busy \\
vs. less busy practice \\
Cost of the equipment, especially for private practices
\end{tabular}

The non-use might lead to non-purchase of the latest models, which might affect the medical device industry. Non-availability apen-use despite availability might also have an impact on patients who mightsequire use of particular EPAs. For example, use of electrotherapy might be useffor for some patients but they might not be provided or treated with the required fer a variety of reasons including lack of scientific evidence of effectiveness Such cases have been suggested as denying a potential benefit for the patient

Other implications of physiotherapy teaching titaining and practice, such as removal of MWD in some text books on evidence based electrotherapy practice ${ }^{20}$ and subsequent effect on undergraduate ourriculum and practical training for EPA.21,33, 51 This shift away from electreftherapy would probably change the nature of physiotherapy practice with lesse electrotherapy and more non-electrotherapeutic treatments in the future. Honcever, accepting or abandoning any EPA without systematic research and scientific evidence cannot be supported. Most commonly, it has been noticed that a lack of clinical effectiveness has been suggested to be the main reason for not using some of these electrotherapy modalities. However, this attitude towards EPAs has been challenged by some practitioners from within the physiotherapist community. For example, Watson ${ }^{2}$ is of the view that there is difference between lack of evidence and evidence of lack and he has suggested that physiotherapists might adopt alternative treatment approaches and use their own experiences and expert opinions when there is no published evidence regarding EPAs. 
Any future research therefore should systematically investigate the issue of lack of clinical effectiveness of electrophysical agents used in physiotherapy practice and suggest recommendations for teaching and training for effective and safe use of EPAs to future physiotherapists.

\section{CONCLUSION}

Of the nine electrophysical agents studied in this review, ultrasound is the most commonly available and used modality across the countries studied during the last 6 twenty years. There is also a high availability and use of interferential, TENS and 1 biofeedback in different countries. PSWD is commonly used in England and the Republic of Ireland compared to Australia; however, its non-use despite equipment availability is higher in Australia and the Republic of Ireland compaced to England. The availability and non-availability of laser is moderate but its rese is declining while non-use despite equipment availability is rising. CSWRers a less commonly available and used modality across the countries and itsanon-availability and use despite device availability is increasing. MWD and modalities and their use is steeply declining whide their non-availability is the highest of all EPAs included in this review

\section{Acknowledgements}

This study was funded by teălth \& Safety Executive, UK (Grant. No. 4371/R47.022).

\section{Conflicts of interest: drone. $^{2}$}

\section{References}

1. Warson T. The role of electrotherapy in contemporary physiotherapy practice. Man ther. 2000;5(3):132-41.

Watson T. Introduction: current concepts and clinical decision making in electrotherapy. In: Watson T, editor. Electrotherapy: Evidence-based practice. 12 ed. Edinburgh: Churchill Livingstone / Elsevier; 2008. p. 3-10.

3. Blum K, Chen A, Chen T, Prihoda T, Schoolfield J, DiNubile N, et al. The H-Wave® device is an effective and safe non-pharmacological analgesic for chronic pain: a meta-analysis Adv Ther. 2008;25(7):644-57.

4. Blum K, Chen A, Chen T, Waite R, Downs BW, Braverman E, et al. Repetitive H-Wave(R) device stimulation and program induces significant increases in the range of motion of 
post operative rotator cuff reconstruction in a double-blinded randomized placebo controlled human study. BMC Musculoskelet Disord. 2009;10(1):132.

5. Turrell WJ. Electrotherapy and its future. Br Med J. 1936;2(3959):1022-6.

6. Tiktinsky R, Chen L, Narayan P. Electrotherapy: yesterday, today and tomorrow. 2010;16:126-31.

7. Gellhorn G. Diathermy in gynecology. JAMA. 1928;90(13):1005-8.

8. Rubin A, Erdman WJ. Microwave exposure of the human female pelvis during early pregnancy and prior to conception: case reports. Am J Phys Med. 1959;38:219-20.

9. Paterson WPE. The treatment of nasal sinus infection by ultra-short wave diathermy. Can Med Assoc J. 1940;42(5):454-6.

10. Sinkus VH. New developments in electrotherapy. Rehab Manag. 1992;5(3):46-7

11. Kitchen SS, Partridge CJ. Review of Shortwave Diathermy Continuous and Pulsed Patterns. Physiother. 1992;78(4):243-52.

12. Hayne CR. Pulsed high frequency energy-its place in physiotherapy, thysiother. 1984;70(12):459-66.

13. Knight KL, Draper DO. Therapeutic modalities: the art and the science. Baltimore, MD.: Lippincott Williams \& Wilkins; 2008.

14. Quirk AS, Newman RJ, Newman KJ. An evaluation of nnterferential therapy, shortwave diathermy and exercise in the treatment of osteoarthrosis of the knee. Physiother. 1985;71 (2):55-7.

15. John L. Dosage of Some Pulsed Shortwaरे Clinical Trials. Physiother. 1995;81(10):6116.

16. Shah SGS, Farrow A, Esnouf A. Availability and use of electrotherapy devices: a survey. Int J Ther Rehabil. 2007;1 $13(6): 260-4$.

17. Kitchen SS, Partridge (XUltrasound, shortwave diathermy and laser: A survey to examine patterns ense in England. Br J Ther Rehab. 1997;4(2):75-8.

18. Chipchase L, Gifliams M, Robertson V. A national study of the availability and use of electrophinsícal agents by Australian physiotherapists. Physiother Theor Pract. 2009:25(4):279-96.

19. Ghepchase LS, Williams MT, Robertson VJ. A framework for determining curricular content of entry level physiotherapy programmes: electrophysical agents as a case study Phys Ther Rev. 2008;13(6):386-94.

20. Watson T, editor. Electrotherapy: Evidence-based practice. 12th edtn. ed. Edinburgh: Churchill Livingstone / Elsevier; 2008.

21. Chipchase LS, Williams MT, Robertson VJ. A survey of electrophysical agents' curricula in entry-level physiotherapy programs in Australia and New Zealand. NZ J Physiother. 2005;33(3):34-48.

22. Chipchase LS, Williams MT, Robertson VJ. Preparedness of new graduate Australian physiotherapists in the use of electrophysical agents. Physiother. 2008;94(4):274-80. 
23. Pope GD, Mockett SP, Wright JP. A survey of electrotherapeutic modalities: Ownership and use in the NHS in England. Physiother. 1995;81(2):82-91.

24. Lindsay D, Dearness J, Richardson C, Chapman A, Cuskelly G. A survey of electromodality usage in private physiotherapy practices. Aust J Physiother. 1990;36(4):249-56.

25. Baxter GD, Bell AJ, Allen JM, Ravey J. Low level laser therapy: Current clinical practice in Northern Ireland. Physiother. 1991;77(3):171-8.

26. Taylor E, Humphry R. Survey of physical agent modality use. Am J Occup Ther. 1991;45(10):924-31.

27. McMeeken J, Stillman B. Perceptions of the clinical efficacy of laser therapy. Aust J Physiother. 1993;39(2):101-8.

28. Kitchen SS. Ultrasound, shortwave diathermy and laser treatment: an exploratory interview study. Br J Ther Rehab. 1995;2(9):495-501.

29. Lindsay D, Dearness J, McGinley C. Electrotherapy usage trends in prifrate physiotherapy practice in Alberta. Physiother Can. 1995;47(1):300?

30. Kitchen SS, Partridge CJ. A survey to examine the clinical usis of ultrasound, shortwave diathermy and laser in England. Br J Ther Rehab. 1996; 3 (12):644-50.

31. Seymour JC, Kerr KM. Community Based Physiotherpy in the Trent Region: A Survey. Physiother. 1996;82(9):514-20.

32. Kitchen SS, Partridge CJ. Ultrasound, shortave diathermy and laser: a survey to examine patterns of use in England. Int Ther Rehab. 1997;4(2):75-8.

33. Robertson VJ, Spurritt D. Electrophosical agents: Implications of their availability and use in undergraduate clinical pacements. Physiother. 1998;84(7):335-44.

34. Partridge CJ, Kitchen SS. Adverse effects of electrotherapy used by physiotherapists. Physiother. 1999;85(6)298-303.

35. Cooney M, Mulling 4 , Gallen C. A survey of electrotherapy modalities: public and private practices in thige Republic of Ireland. Physiother Irel. 2000;21(2):3-8.

36. Shields $\mathrm{N}$ \&ormley J, O’Hare N. Short-wave diathermy in Irish physiotherapy departments. Br J Ther Rehab. 2001;8(9):331-9.

37. Shtelds N, Gormley J, O'Hare N. Short-wave diathermy: current clinical and safety practices. Physiother Res Int. 2002;7(4):191-202.

p38. Warden SJ, McMeeken JM. Ultrasound usage and dosage in sports physiotherapy. Ultrasound Med Biol. 2002;28(8):1075-80.

39. Chipchase LS, Trinkle D. Therapeutic Ultrasound: Clinician Usage and Perception of Efficacy. Hong Kong Physiother J. 2003;21(1):5-14.

40. Al-Mandeel MM, Watson T. An audit of patient records into the nature of pulsed shortwave therapy use. I J Ther Rehab. 2006;13(9):414-20.

41. Tabasam G, Johnson MI. The use of interferential therapy for pain management by physiotherapists. Int J Ther Rehabil. 2006;13(8):357-64. 
42. Wong RA, Schumann B, Townsend R, Phelps CA. A Survey of Therapeutic Ultrasound Use by Physical Therapists Who Are Orthopaedic Certified Specialists. Phys Ther. 2007;87(8):986-94.

43. Scudds RJ, Scudds RA, Baxter GD, McDonough SM, Walsh DM. Transcutaneous Electrical Nerve Stimulation for the Treatment of Pain in Physiotherapy Practices in Hong Kong and the United Kingdom - A Survey of Usage and Perceived Effectiveness Compared With Other Pain Relieving Modalities. Hong Kong Physiother J. 2009;27(1):11-20.

44. Busse JW, Bhandari M. Therapeutic ultrasound and fracture healing: A survey of beliefs and practices. Arch Phys Med Rehab. 2004;85(10):1653-6.

45. Bjordal JM, Johnson MI, Ljunggreen AE. Transcutaneous electrical nerve stimulation 1 (TENS) can reduce postoperative analgesic consumption: a meta-analysis with assessment of optimal treatment parameters for postoperative pain. Eur J Pain. 2003;7:181-8.

46. Johnson M, Martinson M. Efficacy of electrical nerve stimulation for Chronic musculoskeletal pain: a meta-analysis of randomized controlledrtrials. Pain. 2007;130:157-65.

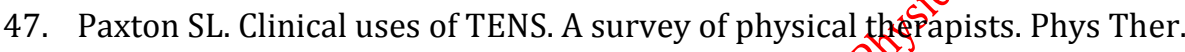
1980;60(1):38-44.

48. Shah SGS, Farrow A. Investigation of practices and procedures in the use of therapeutic diathermy: a study from the physiotherapists health and safety perspective. Physiother Res Int. 2007;12(4):228-41.

49. Kitchen SS. Ultrasound, shortwaye dithermy and laser treatment: an exploratory interview study. Br J Ther Rehabo. 1995;2(8):423-6.

50. Robinson AJ, Snyder-Mackjer L. Clinical application of electrotherapeutic modalities. Phys Ther. 1988;68(8):2323-8.

51. Laakso, E Liisa, Radertson VJ, Chipchase LS. The place of electrophysical agents in Australian ang New Zealand entry-level curricula: is there evidence for their inclusion? Aust J Phy̧ơther. 2002;48(4):251-4.

52. Turnet PA, Whitfield TWA. Physiotherapists' use of evidence based practice: a crossnational study. Physiother Res Int. 1997;2(1):17-29.

53. Turner PA, Harby-Owren H, Shackleford F, So A, Fosse T, Whitfield TWA. Audits of physiotherapy practice. Physiother Theory Pract. 1999;15(4):261 - 74.

54. ter Haar G, Dyson M, Oakley EM. Ultrasound in physiotherapy in the United Kingdom: Results of a questionnaire. Physiother Pract. 1988;4(2):69-72. 